Article

\title{
High-Durability Concrete Using Eco-Friendly Slag-Pozzolanic Cements and Recycled Aggregate
}

\author{
Klaus Voit ${ }^{1}\left(\mathbb{D}\right.$, Oliver Zeman ${ }^{2, *} \mathbb{B}$, Ivan Janotka ${ }^{3}$, Renata Adamcova ${ }^{4}$ and Konrad Bergmeister ${ }^{2}$ \\ 1 Institute of Applied Geology, Department of Civil Engineering and Natural Hazards, University of Natural \\ Resources and Life Sciences, Peter Jordan-Street 82, 1190 Vienna, Austria; klaus.voit@boku.ac.at \\ 2 Institute of Structural Engineering, Department of Civil Engineering and Natural Hazards, University of \\ Natural Resources and Life Sciences, Peter Jordan-Street 82, 1190 Vienna, Austria; \\ konrad.bergmeister@boku.ac.at \\ 3 Department of Material Research, Building Testing and Research Institute, Studena 3, 82104 Bratislava, \\ Slovakia; janotka@tsus.sk \\ 4 Department of Engineering Geology, Faculty of Natural Sciences, Comenius University in Bratislava, \\ Ilkovicova 6, 84215 Bratislava, Slovakia; renata.adamcova@uniba.sk \\ * Correspondence: oliver.zeman@boku.ac.at
}

Received: 14 October 2020; Accepted: 18 November 2020; Published: 23 November 2020

\begin{abstract}
Clinker production is very energy-intensive and responsible for releasing climate-relevant carbon dioxide $\left(\mathrm{CO}_{2}\right)$ into the atmosphere, and the exploitation of aggregate for concrete results in a reduction in natural resources. This contrasts with infrastructure development, surging urbanization, and the demand for construction materials with increasing requirements in terms of durability and strength. A possible answer to this is eco-efficient, high-performance concrete. This article illustrates basic material investigations to both, using eco-friendly cement and recycled aggregate from tunneling to produce structural concrete and inner shell concrete, showing high impermeability and durability. By replacing energy- and $\mathrm{CO}_{2}$-intensive cement types by slag-pozzolanic cement (CEM V) and using recycled aggregate, a significant contribution to environmental sustainability can be provided while still meeting the material requirements to achieve a service lifetime for the tunnel structure of up to 200 years. Results of this research show that alternative cements (CEM V), as well as processed tunnel spoil, indicate good applicability in terms of their properties. Despite the substitution of conventional clinker and conventional aggregate, the concrete shows good workability and promising durability in conjunction with adequate concrete strengths.
\end{abstract}

Keywords: green cements; slag-pozzolanic cement; CEM V; tunnel spoil recycling; high durability

\section{Introduction}

\subsection{Eco-Efficient Cement Production}

The demand for concrete-the world's most used construction material—continues to remain at a high level notwithstanding recent global economic fluctuations. In doing so, the concrete industry acts as one of the main contributors to $\mathrm{CO}_{2}$ emissions accounting for approx. 5 to $7 \%$ of global anthropogenic $\mathrm{CO}_{2}$ emissions (see [1-4]), whereby Portland cement production accounts for approx. $90 \%$ of the quoted share [5]. The rapid increase in the recent global cement production is driven by China, which produced 2.35 gigatons of cement in 2015. This corresponds to $55 \%$ of the global amount of cement produced, contributing approximately 13 to $15 \%$ of China's total $\mathrm{CO}_{2}$ emissions. In the future, due to population growth, cement production worldwide is projected to increase between $12 \%$ and $23 \%$ by the year 2050 [6]. 
Such production quantities would lead to a global emission, depending on the author, of approximately 1.3 to 1.8 billion tons of $\mathrm{CO}_{2}$ per year [2,7]. Further, $\mathrm{CO}_{2}$ emission during cement production is derived from two sources, having a similar share: (1) Process-related $\mathrm{CO}_{2}$ accounting for the energy demand by the use of fuels and electric energy mainly for drying, grinding, and mostly from clinker burning; (2) the emission of embodied $\mathrm{CO}_{2}\left(\mathrm{ECO}_{2}\right)$ during $\mathrm{CaCO}_{3}$ decomposition during heating, when the chemically bound $\mathrm{CO}_{2}$ from the carbonate rock is degassing [2,5]. Summed up, the amount of generated $\mathrm{CO}_{2}$ per kilogram of produced clinker varies between 0.65 and $1.0 \mathrm{~kg} \mathrm{CO}$ per $\mathrm{kg}$ clinker [8-11] depending on the fuel type and the basis of electricity production. The process-related global $\mathrm{CO}_{2}$ emission of concrete has been estimated at approximately $83 \mathrm{~kg} \mathrm{CO}_{2}$ per ton by [12], while $\mathrm{ECO}_{2}$ accounts for an additional amount of approximately 95 to $135 \mathrm{~kg} / \mathrm{ton}$, varying depending on the specific concrete design $[5,13,14]$, adding up to the generation of roughly $200 \mathrm{~kg} \mathrm{CO}_{2}$ per ton of concrete.

In view of the importance of these issues, measures have been taken to reduce the environmental implications of cement and concrete production by using various strategies. The options range from customized concrete mixing design and plant technology possibilities toward energy saving [15] to carbon capture strategies $[16,17]$. As a very central point with regard to embodied $\mathrm{CO}_{2}$, the usage of alternative raw materials with the absence of carbonates in their mineral content is effective. This means the reduction in the portion of Portland cement replacing the clinker by alternative binder compositions (e.g., fly ash, furnace slag, or natural pozzolans) producing blended or-when using more than one blending material-so-called composite cements [18-20]. A current strategy in this context is the substitution of clinker by waste-based cementing materials, i.e., [19,21]. In the present article, the approach of slag-pozzolanic cements (CEM V) according to [22] is pursued.

\subsection{Aggregate Recycling}

Additionally, next to or supplementary to clinker optimization, aggregate recycling has a positive effect on the environmental impact of concrete production. Aggregate production is not particularly significant concerning $\mathrm{CO}_{2}$ emission and energy consumption compared to cement production, but due to the large quantities and the high percentage by weight (approx. $80 \mathrm{wt} \%$ ) of conventional concrete consisting of aggregate, the impact on natural resources is considerably high. Referring to this, aggregate material in particular in close range to the demand with no other intended use can be considered a potential substitute for natural aggregate, provided all crucial technical and legal requirements are met. This applies to construction and demolition waste (CDW), as well as natural excavated rock material. The use of construction and demolition waste as aggregate is the content of current research, e.g., $[21,23,24]$.

Likewise, excavated rock material from earthworks and tunneling is intended to be recycled as aggregate for concrete $[25,26]$. Due to the fact that, particularly during tunneling, large volumes of concrete are used, there are efforts to reduce the ecological impact of such construction projects at the same time. As for concrete, this concerns cement, as discussed in Section 1.1, and the aggregate used. Regarding the reuse of tunnel spoil, there are numerous related studies examining the questions of reuse possibilities and the suitability of excavated rock for aggregate production. Aspects of tunnel muck recycling and tunnel spoil application opportunities have been demonstrated [27,28]. Therefore, the type of tunnel driving method has a major influence on excavated rock characteristics; this question is evaluated by [29-31]. For high-quality concrete production, careful planning, efficient rock classification [32], and rock material management [33], as well as technical considerations focusing on material analysis and data management, are fundamental [34], not to forget the juridical considerations, as tunnel spoil can initially be considered as waste from a legal point of view, which is done by $[35,36]$.

Tunnel structures have high construction costs and, once in operation, are counted among critical infrastructure. Therefore, for these structures, a service lifetime of some hundred years is assumed. Therefore, durability is a primary focus of the admixture designs. Besides static requirements, a reliable performance capability must be guaranteed for this time period. To meet this requirement, 
high-performance concrete in terms of durability and density is generally applied in tunnel structures [37]. During construction of the Swiss pioneer projects of the Base Tunnels at the Lötschberg and Gotthard massif, approximately $40 \%$ and $35 \%$, respectively, of the tunnel spoil was recycled mainly for the production of aggregate for concrete [38-40]. A concrete quality with high resistance against various environmental influences allowed the design for a projected service lifetime of 100 years [38].

This research addresses aggregate recycling from tunneling from the example of the high-priority infrastructure project of the Brenner Base Tunnel. The Brenner Base Tunnel is an approx. $55 \mathrm{~km}-\mathrm{long}$, flat railway tunnel project acting as a connecting link between Austria and Italy and the main element of the new Brenner railway from Munich to Verona. The tunnel is currently under construction, with a service lifetime designed for a lifespan of 200 years. This increased service lifetime is achieved by a high durability of concrete, accomplished by the high quality of raw materials and good processing of concrete, whereby a high density and impermeability of concrete have the greatest impact [37]. In addition, preliminary tests combining recycled tunnel spoil with slag-pozzolanic cements were conducted.

\subsection{Aims, Materials, and Methods}

The overall aims of the presented research can be summarized and listed as follows:

- creating various slag-pozzolanic cement admixtures reducing the clinker component while still exhibiting suitable binder properties

- characterization of the different cementitious constituents used to produce the slag-pozzolanic CEM V cement types

- identifying the cement characteristics of the designed CEM V cement types

- developing concrete formulas and gathering the concrete properties using the manufactured CEM $\mathrm{V}$ cements

- further ecological improvement by replacement of the standard aggregate by recycled aggregate for concrete

- acquiring the basic characteristics of the developed concrete mixtures with a focus on concrete durability

To reach the desired objectives, binder and concrete manufacture, as well as intensive material testing, was performed including the following: (1) Various testing methods were applied to characterize at first the cement admixtures and cement properties of the produced CEM V cement types:

- X-ray diffraction analysis XRD (Philips X-ray diffractometer PW1730, Malvern Panalytical GmbH, Kassel, Germany) to examine the mineralogical composition,

- X-ray fluorescence XRF (PANalytical X`Pert Pro, Malvern Panalytical GmbH, Kassel, Germany) to record the chemical composition,

- Frattini-testing to demonstrate the pozzolanic activity of the cementitious constituents,

- fresh cement mortars testing (slump, density, air content, setting time, soundness),

- hardened cement mortars testing (recording compressive strength and bending tensile strength at $2,7,28,56$, and 84 days of curing time to gather strength development data as well) with an additional focus on the durability-relevant parameters, porosity and passivation ability.

Subsequently, (2) standard concrete compositions using the generated cements were tested to identify the concrete characteristics:

- fresh concrete testing (flow, density, air content)

- hardened concrete testing (compressive strength, bending tensile strength, modulus of elasticity) with a focus on the durability-relevant parameters, frost-resistance and permeability

In a third step, (3) standard aggregate for concrete was replaced by recycled aggregate from nonstandard crushed metamorphic rock arising during tunnel excavation. These concrete 
mixtures-now consisting of a newly developed CEM V cement admixture and processed and recycled aggregate from schist rocks-were also examined with regard to workability (fresh concrete density, flow spread, air content), strength (compressive and bending tensile strength, as well as the fracture energy), and particularly with regard to durability, as the designed concrete composition may be used in tunnel constructions, where the recycled aggregate is generated, exhibiting long service lifetimes of up to 200 years.

At all investigation levels, an additional comparison to standard cement was made.

\section{Slag-Pozzolanic CEM V Characteristics}

\subsection{General}

To produce cements with reduced $\mathrm{CO}_{2}$ impact, the strategy of Portland cement substitution by additional cementitious constituents, in this case, fly ash (FA), granulated blast-furnace slag (S), and natural pozzolana (P), in accordance with the cement standard EN 197-1 [22], was pursued in this research to produce slag-pozzolanic cement CEM V.

In contrast to the previous edition of EN 197-1, which was valid until Spring 2018, the 27 products in the family of common cements were extended to 39 products until now, inter alia, adding the main cement type CEM VI "composite cement" (having a limestone content from 6 to $20 \mathrm{wt} \%$ ), and the former CEM V "composite cement" had been renamed to CEM V "slag-pozzolanic cement." The latter consists of 40 to $64 \mathrm{wt} \%$ clinker, 18-30 wt\% blast-furnace slag, and 18-30 wt\% Pozzolana and siliceous fly ash in the case of CEM V/A, and of 20 to $38 \mathrm{wt} \%$ clinker, 31-49 $\mathrm{wt} \%$ blast-furnace slag, and 31-49 $\mathrm{wt} \%$ Pozzolana and siliceous fly ash for CEM V/B, whereby minor additional constituents (gypsum and limestone for instance) are possible up to $5 \mathrm{wt} \%$ for both types.

The increase concerning cement products expresses the research performance and interest of the cement industry in additional cement types with the substitution of clinker by different constituents. The use of these additional cementitious constituents modifies the characteristics of the produced concrete. In the case of CEM V cements, early strength is naturally reduced by the pozzolanic reaction of $\mathrm{SiO}_{2}$ and $\mathrm{Al}_{2} \mathrm{O}_{3}$ from fly ash or natural pozzolana and the latent hydraulic reaction of blast furnace slag, and therefore, is not suitable for fast-track construction. This can be overcome by the additional application of silica fume (SF) [5,41]. Then again, improvement in the long-term performance of concrete is indicated by using blended cements due to the delayed growth of calcium silicate hydrate $(\mathrm{CSH})$ and aluminate phases, growing into the pores, providing an increased density of the concrete structure, e.g., [42-44].

However, in many European countries, the application of CEM V cement is not allowed (e.g., Austria) or is restricted (e.g., Germany) by national concrete standards (ÖNORM B 4710-1 [45] in the case of Austria or DIN 1045-2 [46] in the case of Germany), mainly due to the lack of experience. Therefore, in the course of this research, material characterization of the following four manufactured CEM V cement types was carried out to examine the performance of CEM V cements and concrete produced with CEM V cement:

(1) CEM V/A (S-V) $32.5 \mathrm{R}$ and

(2) $\mathrm{CEM} \mathrm{V/B} \mathrm{(S-V)} 32.5 \mathrm{~N}$ based on slag and fly ash were produced in a cement plant in Austria;

(3) CEM V/A (S-V) $32.5 \mathrm{R}$, based on slag and fly ash, and

(4) CEM V/B (S-P) $32.5 \mathrm{~N}$ using blast furnace slag and natural pozzolana (zeolite) as the main constituents were produced in a Slovak cement factory.

In doing so, a significant reduction in the cement clinker content to a level of $45.1 \mathrm{wt} \%$ (1), $26.9 \mathrm{wt} \%$ (2), $52.9 \mathrm{wt} \%$ (3), and $30.9 \mathrm{wt} \%$ (4) for each individual cement type was achieved [47]. The proportional composition of the cementitious constituents in the case of (1) and (2) was $40 \mathrm{wt} \% \mathrm{slag}$, $50 \mathrm{wt} \%$ fly ash, and $10 \mathrm{wt} \%$ limestone. In the case of (3) and (4), the additives were added in equal shares in both cases. 


\subsection{Basic Cement Qualities}

\subsubsection{Cementitious Constituents}

Subsequent to the manufacturing of the different CEM V cement types, testing of the main cement properties was performed (see also [47]). In a first step, the main chemical properties of the cementitious constituents of (3) and (4) were compared by X-ray fluorescence to illustrate the fundamentally different chemical composition of fly ash (FA), blast furnace slag (S), and the pozzolana zeolite (P) (see Table 1). In the case of FA and the natural pozzolana zeolite $(\mathrm{P}), \mathrm{SiO}_{2}$ and $\mathrm{Al}_{2} \mathrm{O}_{3}$ contents are-compared to S-high, suggesting high pozzolanic activity (see also Table 2).

Table 1. Chemical properties of cementitious constituents of (3) CEM V/A (S-V) 32.5 R and (4) CEM V/B (S-P) 32.5.

\begin{tabular}{cccc}
\hline Compound & \multicolumn{3}{c}{ Mass Percentage [wt\%] } \\
& Fly Ash (FA, V) & Blast Furnace Slag (S) & Pozzolana Zeolite (P) \\
\hline $\mathrm{SiO}_{2}$ & 57.8 & 41.2 & 61.4 \\
$\mathrm{Al}_{2} \mathrm{O}_{3}$ & 17.9 & 6.2 & 11.5 \\
$\mathrm{Fe}_{2} \mathrm{O}_{3}$ & 7.4 & 0.5 & 1.4 \\
$\mathrm{CaO}$ & 4.2 & 37.2 & 3.5 \\
$\mathrm{MgO}$ & 6.3 & 10.1 & 4.3 \\
$\mathrm{SO}_{3}$ & 2.6 & 2.8 & 3.3 \\
$\mathrm{Na}_{2} \mathrm{O}$ & 1.4 & 1.4 & 1.3 \\
$\mathrm{~K}_{2} \mathrm{O}$ & 1.3 & 0.4 & 1.6 \\
Loss on ignition & 1.1 & 0.0 & 12.2 \\
\hline
\end{tabular}

Table 2. Pozzolanic activity of cementitious constituents (by Frattini-test).

\begin{tabular}{|c|c|c|c|}
\hline \multirow[t]{2}{*}{ Compound } & \multicolumn{3}{|c|}{ Bounded $\mathrm{CaO}$ by Pozzolanic Additives $\left[\mathrm{mmol} / \mathrm{L}\right.$ and $\left(\%\right.$ in Saturated $\mathrm{Ca}(\mathrm{OH})_{2}$ Solution)] after } \\
\hline & 1 Day & 7 Days & 28 Days \\
\hline Fly ash (FA) & $5.6(25)$ & $12.7(57)$ & $19.5(87)$ \\
\hline Blast furnace slag (S) & $7.5(34)$ & $10.4(47)$ & $12.8(57)$ \\
\hline Pozzolana Zeolite (P) & $19.2(86)$ & $21.2(95)$ & $21.7(97)$ \\
\hline
\end{tabular}

Blast furnace slag (S) shows similarly high values of $\mathrm{SiO}_{2}$ with $41.2 \mathrm{wt} \%$ and a high $\mathrm{CaO}$ and $\mathrm{MgO}$ content of 37.2 and $10.1 \mathrm{wt} \%$, respectively. Loss on ignition is relatively high in the case of Pozzolana, because of the chemically bound water from clinoptilolite $\left[(\mathrm{Na}, \mathrm{K}, \mathrm{Ca})_{2}{ }_{3} \mathrm{Al}_{3}\left(\mathrm{Al}, \mathrm{Si}_{2} \mathrm{Si}_{13} \mathrm{O}_{36} \cdot 12 \mathrm{H}_{2} \mathrm{O}\right]\right.$.

$\mathrm{XRD}$ of the cementitious constituents' analysis again provides further information on the degree of crystallinity by interpretation of the peak visualization: Broader, less distinct peaks suggest low crystallinity, while explicit and high peaks indicating the opposite. XRD diagrams of the raw materials used show the following (Figure 1): FA consists of well-crystallized $\mathrm{SiO}_{2}$ and portions of anorthite (Calcium Feldspar), while the Ca- and Mg-aluminosilicates are diffuse and show a low crystalline grade without any distinct higher-intensity peak (Figure 1). Blast furnace slag (S) can be described as poorly crystallized, showing two major peaks indicating ferrite and belite phases, and also consisting of other, different burned phases (see Figure 1). By contrast, the natural pozzolana zeolite (P) consists of the well-crystallized tectosilicate Clinoptilite (numerous high-intensity single peaks with the main intensity at angles $2 \Theta$ of 11.3 and 22.5).

Pozzolanic activity of the cementitious constituents was tested using Frattini's testing method according to [48] by the solution of $20 \mathrm{~g}$ of cement in $100 \mathrm{~mL}$ of water at $40{ }^{\circ} \mathrm{C}$ for varying periods $(1,7$, and $28 \mathrm{~d})$, measuring the calcium and hydroxide ion values, calculating the oxide-bounded $\mathrm{Ca}$, and comparing the bounded $\mathrm{CaO}$ to the calcium oxide solubility isotherm curve ( $\%$ of bounded $\mathrm{CaO}$ ) (Table 2). 


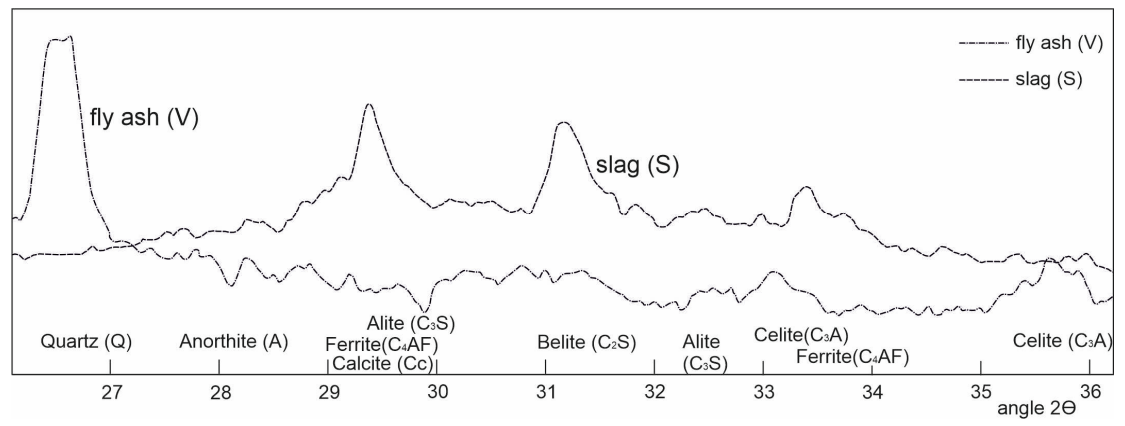

Figure 1. XRD diagrams displaying angle $2 \Theta$-intensities of cementitious constituents fly ash (V) and furnace slag $(\mathrm{S})$, whereby: Alite $-3 \mathrm{CaO} \times \mathrm{SiO}_{2} ;$ Belite $-2 \mathrm{CaO} \times \mathrm{SiO}_{2} ;$ Celite $-2 \mathrm{CaO} \times \mathrm{Al}_{2} \mathrm{O}_{3}$; Ferrite- $4 \mathrm{CaO} \times \mathrm{Al}_{2} \mathrm{O}_{3} \times \mathrm{Fe}_{2} \mathrm{O}_{3}$.

Table 2 clearly shows that $\mathrm{CaO}$ is very rapidly and most strongly bound by the pozzolana zeolite, bounding approximately $97 \%$ of $\mathrm{CaO}$ after a period of 28 days. This is achieved by the high $\mathrm{SiO}_{2}$ and low $\mathrm{CaO}$ content, cf. Table 1, resulting in a high pozzolan activity.

\subsubsection{Cement Properties and Composition}

Following the manufacture of the four different above-mentioned CEM V cement types (1), (2), (3), and (4) (see Section 2.1), cement testing was conducted to determine the key characteristics [49]. Fundamental characteristics are cement true density and specific surface expressed as a Blaine-value, illustrated in Table 3 for the manufactured CEM V cement types, as well as for the CEM I basic product.

Table 3. Cement true density and Blaine value.

\begin{tabular}{ccc}
\hline Cement Type & True Density $\left[\mathbf{k g} / \mathbf{m}^{3}\right]$ & Blaine-Value $\left[\mathbf{c m}^{\mathbf{2}} / \mathbf{g}\right]$ \\
\hline CEM I 32.5 R & 3088 & 3560 \\
(1) CEM V/A (S-V) 32.5 R & 2876 & 5343 \\
(2) CEM V/B (S-V) 32.5 N & 2857 & 4392 \\
(3) CEM V/A (S-V) 32.5 R & 2741 & 4484 \\
(4) CEM V/B (S-P) 32.5 N & 2790 & 4770 \\
\hline
\end{tabular}

An important parameter with regard to chemical composition and environmental impact is the $\mathrm{CaO}$-content of the various cement products. The lower the content of $\mathrm{CaO}$, the lower the amount of $\mathrm{ECO}_{2}$ (see Section 1.1) emitted. On the other hand, the CaO-containing components in hydrated cement are most sensitive to any aggressive attack; therefore, reducing the $\mathrm{CaO}$ content in the blended cement is a key condition for the expected improvement in the durability of the cement composites, see Section 2.4. Figure 2 illustrates the $\mathrm{CaO}$ content derived by $\mathrm{X}$-ray fluorescence.

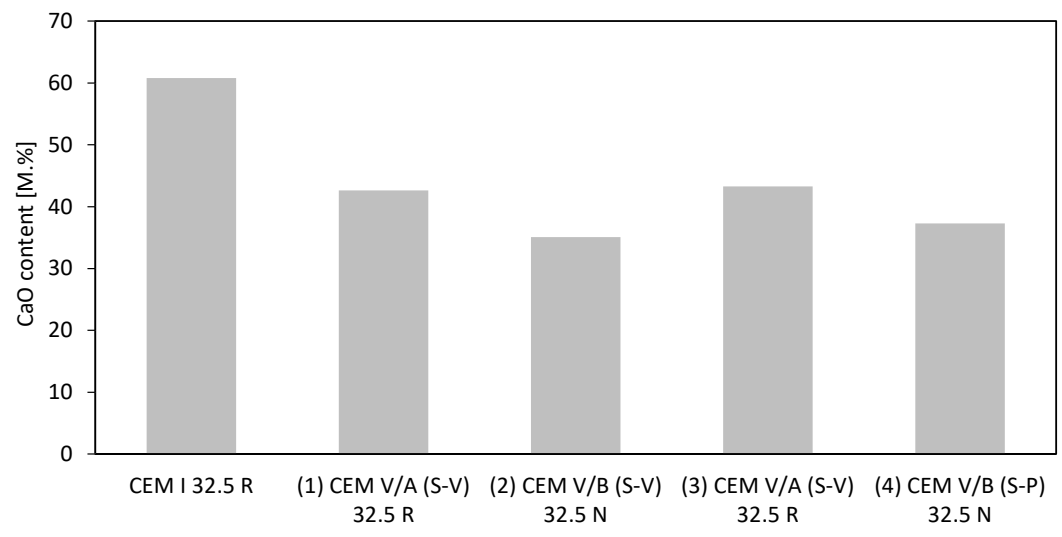

Figure 2. $\mathrm{CaO}$ content of the various CEM V cement types. 
Figure 1 clearly shows the reduced amount of $\mathrm{CaO}$ in CEM V cements (replaced by $\mathrm{SiO}_{2}$ and $\mathrm{Al}_{2} \mathrm{O}_{3}$ from cementitious constituents, see Table 1) compared to Portland clinker CEM I. Particularly, the CEM V/B with a much higher proportion of additives shows a comparable low $\mathrm{CaO}$ content.

Cement analysis via X-ray diffraction (Figure $3 a, b)$ shows an amorphous content in each case, expressed by a slightly broader and diffuse appearance of the peaks, whereby the glassy, noncrystalline phases originate from blast furnace slag and fly ash, cf. Figure 1. Referring to this, cement type (1) and (2) present the highest amorphous content. Furthermore, CEM V/B (S-P) shows the lowest level of amorphous components due to the well-crystallized Clinoptilite (see also [47]).

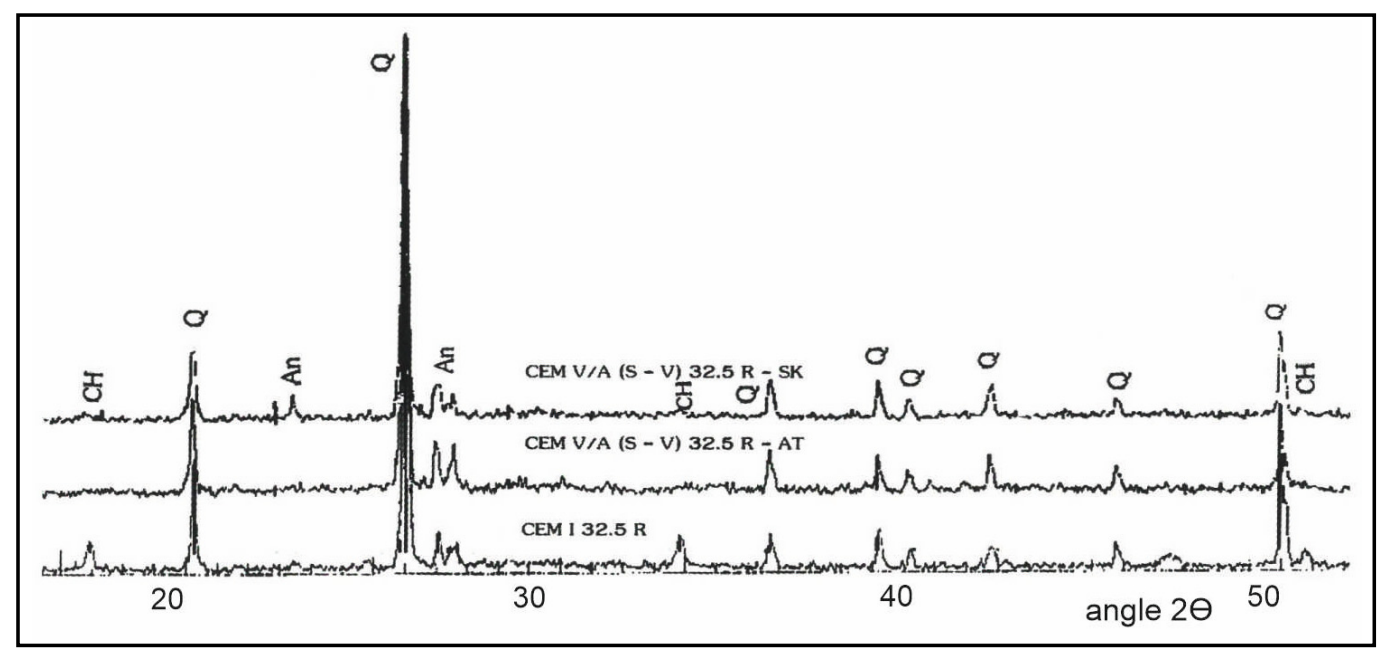

(a)

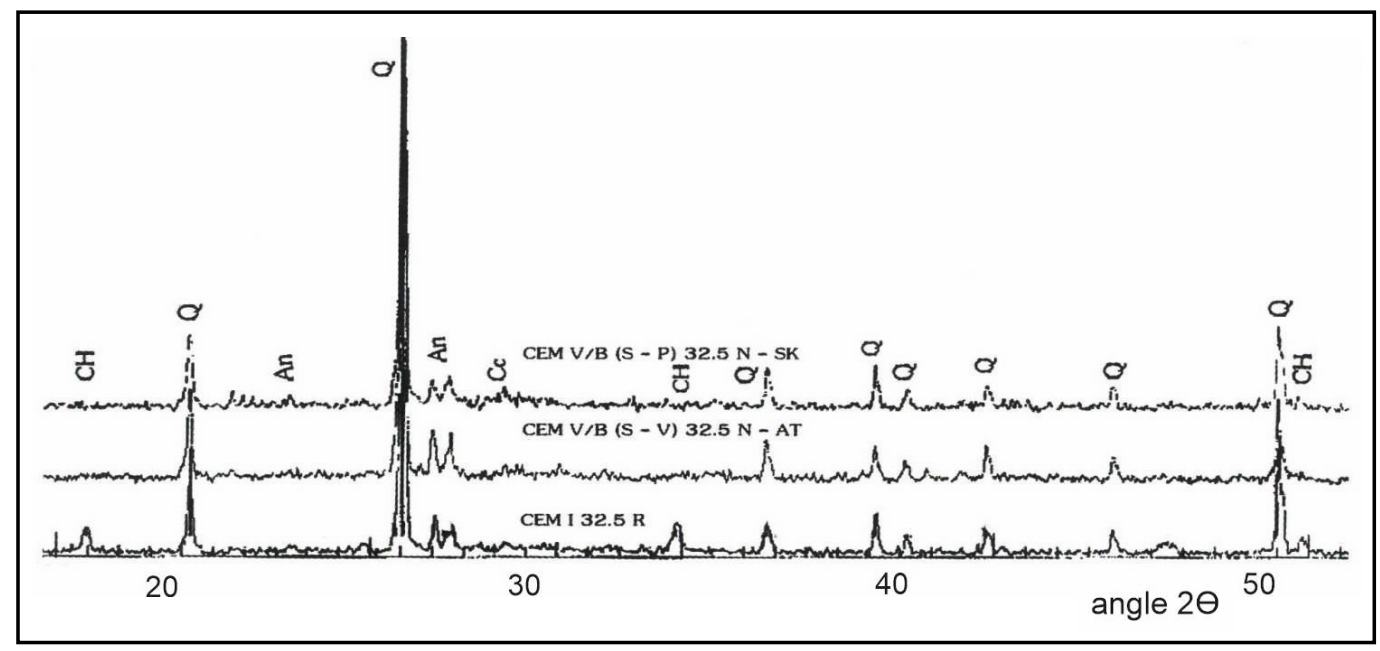

(b)

Figure 3. XRD diagrams displaying angle $2 \Theta$-intensities of (a) CEM V/A types and reference cement $\mathrm{CEM} \mathrm{I}$ and (b) CEM V/B types and reference cement CEM Iafter 365 days curing at $20^{\circ} \mathrm{C}$ under water, whereby: $\mathrm{CH}$-portlandite $\mathrm{Ca}(\mathrm{OH})_{2} ; \mathrm{Cc}$-calcite, $\mathrm{Q}$ - quartz $\mathrm{SiO}_{2}$, An—anorthite $\left(\mathrm{CaAl}_{2} \mathrm{Si}_{2} \mathrm{O}_{8}\right)$.

\subsection{Cement Mortars Properties}

To evaluate fresh and hardened cement paste properties, fresh mortar and the derived test specimens according to [50] were produced, cf. [47,49]. Therefore, test sand was mixed with cement at a ratio 3 to 1 and the corresponding amount of water to reach a water/cement ratio of 0.5 [49]. The fresh mortar properties slump, density, and air content, as well as setting time and soundness according to [51], are illustrated in Table 4, providing information about performance and workability of the tested cement types. 
Table 4. Fresh mortar properties of different CEM V cements.

\begin{tabular}{ccccccc}
\hline Cement Type & $\begin{array}{c}\text { Slump Value } \\
{[\mathbf{m m}]}\end{array}$ & $\begin{array}{c}\text { Density } \\
{\left[\mathbf{k g} / \mathbf{m}^{\mathbf{3}}\right]}\end{array}$ & $\begin{array}{c}\text { Air Content } \\
{[\%]}\end{array}$ & $\begin{array}{c}\text { Init. Setting } \\
\text { Time [min] }\end{array}$ & $\begin{array}{c}\text { Final Setting } \\
\text { Time [min] }\end{array}$ & $\begin{array}{c}\text { Soundness } \\
{[\mathbf{m m}]}\end{array}$ \\
\hline CEM I 32.5 R & 155 & 2230 & 4.5 & 210 & 265 & 0.5 \\
$\begin{array}{c}\text { (1) CEM V/A } \\
\text { (S-V) 32.5 R }\end{array}$ & 175 & 2220 & 4.1 & 265 & 320 & 0.5 \\
$\begin{array}{c}\text { (2) CEM V/B } \\
\text { (S-V) 32.5 N }\end{array}$ & 166 & 2220 & 3.7 & 350 & 420 & 1.0 \\
$\begin{array}{c}\text { (3) CEM V/A } \\
\text { (S-V) 32.5 R }\end{array}$ & 135 & 2150 & 4.4 & 270 & 340 & 0.5 \\
$\begin{array}{l}\text { (4) CEM V/B } \\
\text { (S-P) 32.5 N }\end{array}$ & 106 & 2060 & 5.3 & 230 & 330 & 1.0 \\
\hline
\end{tabular}

Cement types (3) and (4) show comparatively low slump values, indicating the need of superplasticizers to reach a reasonable workability of the fresh mortar. By using a super-plasticizer with a dosage of approximately $0.5 \mathrm{wt} \%$ of the cement weight, the slump values were increased to the same level compared to (1) and (2). The fresh mortar density of CEM V/B types is lower than that of the CEM V/A types due to the lower density of the cementitious constituents compared to Portland cement clinker. The density of cement type (4) is noticeably low, due to the porous tectosilicate structure of zeolite that is probably also responsible for the comparably high air content. Setting time of the CEM V mortars is naturally delayed due to the posterior pozzolanic and latent hydraulic reactions of the additives. Soundness of all cement types falls significantly below the limit value of $10 \mathrm{~mm}$ according to [51], showing satisfactory volume consistency.

The compressive and bending tensile strength of hardened mortar specimens were determined for a basic mechanical characterization according to [50] with due regard to strength development with time; see Figure 4 for the concrete compressive strength and Figure 5 for the bending tensile strength.

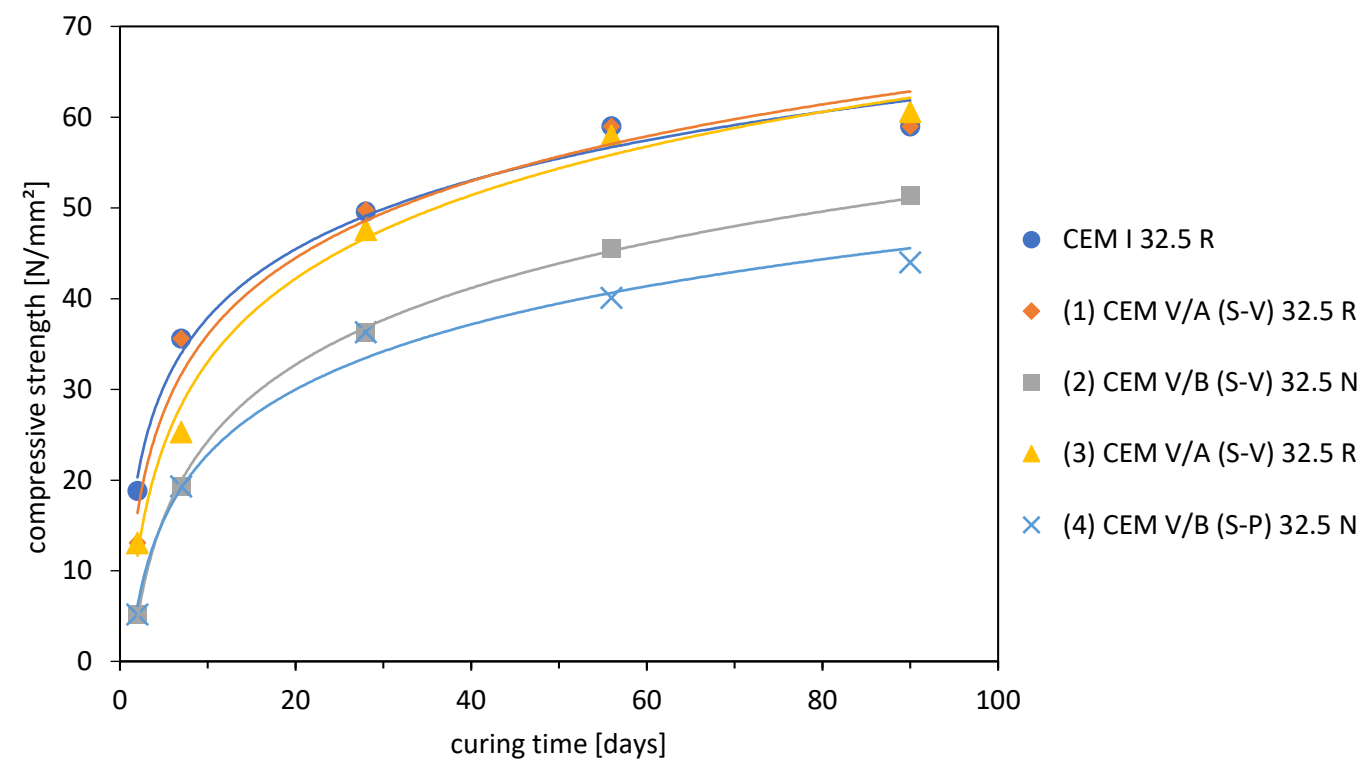

Figure 4. Compressive strength development of standard mortar specimens according to [51] (each value as a mean value of 3 individual tests), after 2, 7, 28, 56, and 90 days. 


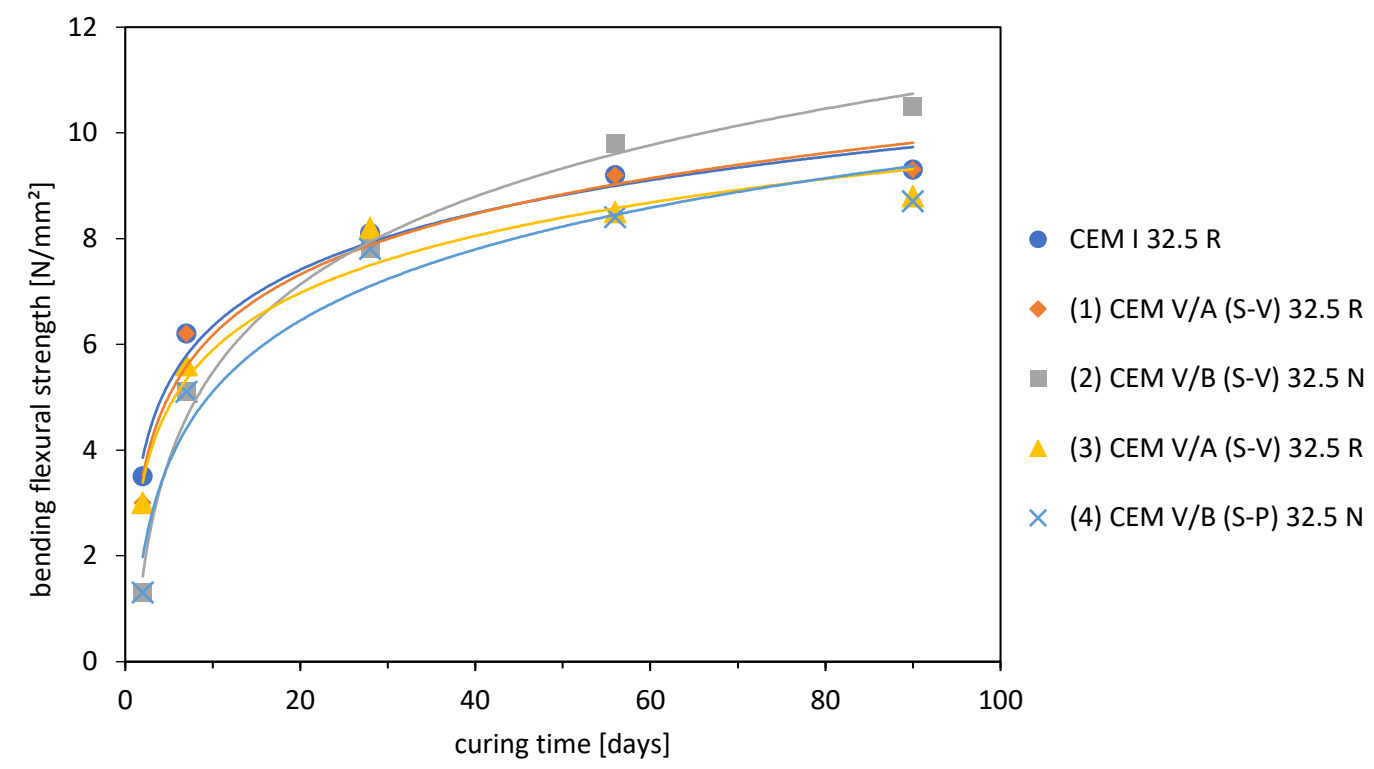

Figure 5. Bending flexural strength development of standard mortar prisms according to [51] (each value as mean value of 3 individual tests), after 2, 7, 28, 56, and 90 days.

The strength development of the considered cement types delivered the expected behavior: Standard cement CEM I 32.5 R reaches high early strength, though the CEM V/A cement types reach an equal strength level between 7 and 56 days of curing time. CEM V/B types lag behind but still show an increase in strength even after 56 days in contrast to CEM I and CEM V/A types.

Considering bending flexural strength (Figure 5), all cement types reach a similar strength level after 28 days of water curing. Subsequently, cement type (2) CEM V/B (S-V) is the only cement type still exhibiting a significant increase in flexural bending strength.

By using a super-plasticizer with a dosage of $0.5 \mathrm{wt} \%$ of the cement weight to improve the fresh mortar slump value of individual mixtures (cf. Table 4), the 28 day compressive strength for cement type (3) and (4) could be increased by approximately $10 \%$, reaching a compressive strength of 52.1 and $40.3 \mathrm{~N} / \mathrm{mm}^{2}$, respectively.

\subsection{Durability Aspects}

Pore structure and the resulting permeability are key indicators to evaluate the durability of hardened cement paste and concrete. The appearance of the pore structure of cement paste and concrete is mainly influenced by the cement type. The delayed reaction of pozzolanic or hydraulic additives leads to the growth of additional CSH-phases-by consuming and reducing the $\mathrm{Ca}(\mathrm{OH})_{2-}$ content and a lower heat of hydration. As a result, the permeability and porosity of the paste or concrete is considerably reduced, as well as thermally induced cracking, which ensures an increased resistance against sulfate and chloride ions attack. Furthermore, due to the low availability of alkali in FA and S, the alkali reaction of cement with reactive components from the aggregate is inhibited, e.g., [52,53].

Pore structure was analyzed in detail for the tested cement types from hardened cement paste [47]. Therefore, the focus was laid on total pore content and the percentage of macro-pores with a diameter $>50 \mathrm{~nm}$, because the latter has a negative impact on concrete structure, particularly with regard to durability. Using mercury porosimetry according to [54,55], pore characterization was performed as shown in Figures 6 and 7. 


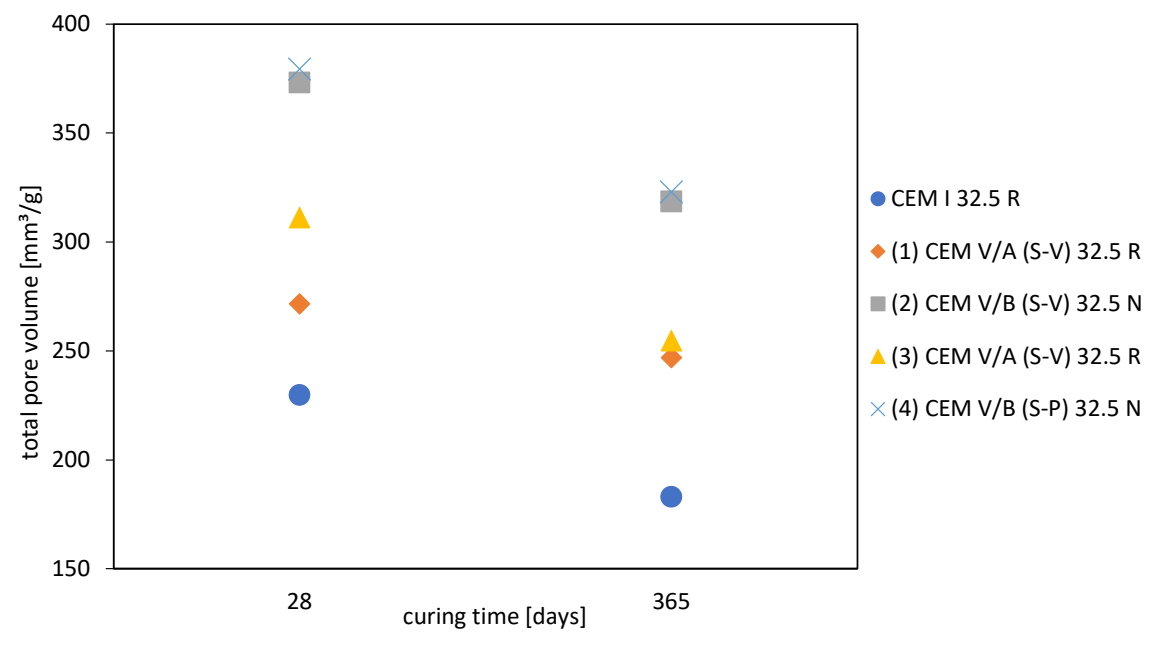

(a)

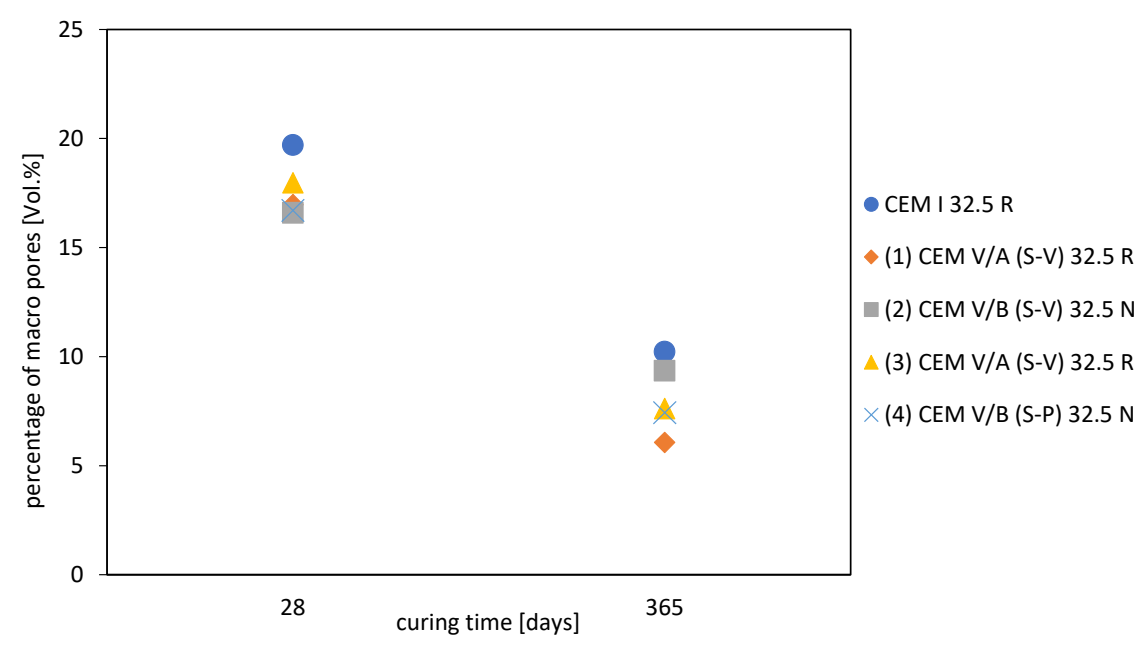

(b)

Figure 6. Development of total porosity (a) and percentage of macro-porosity (b) for a curing time of 28 and 365 days.

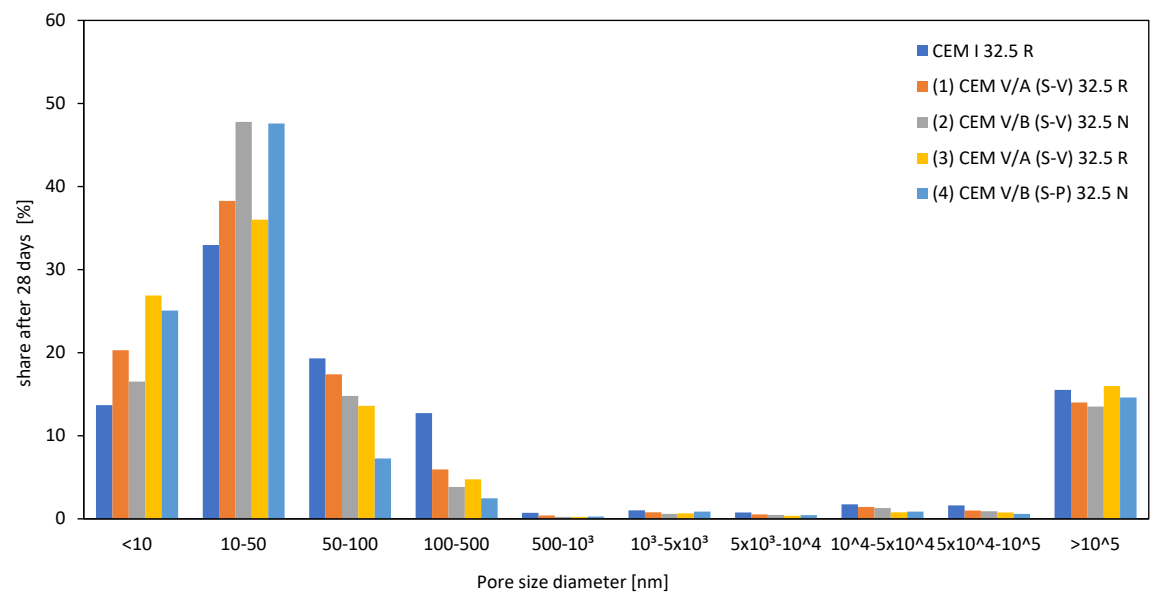

(a)

Figure 7. Cont. 


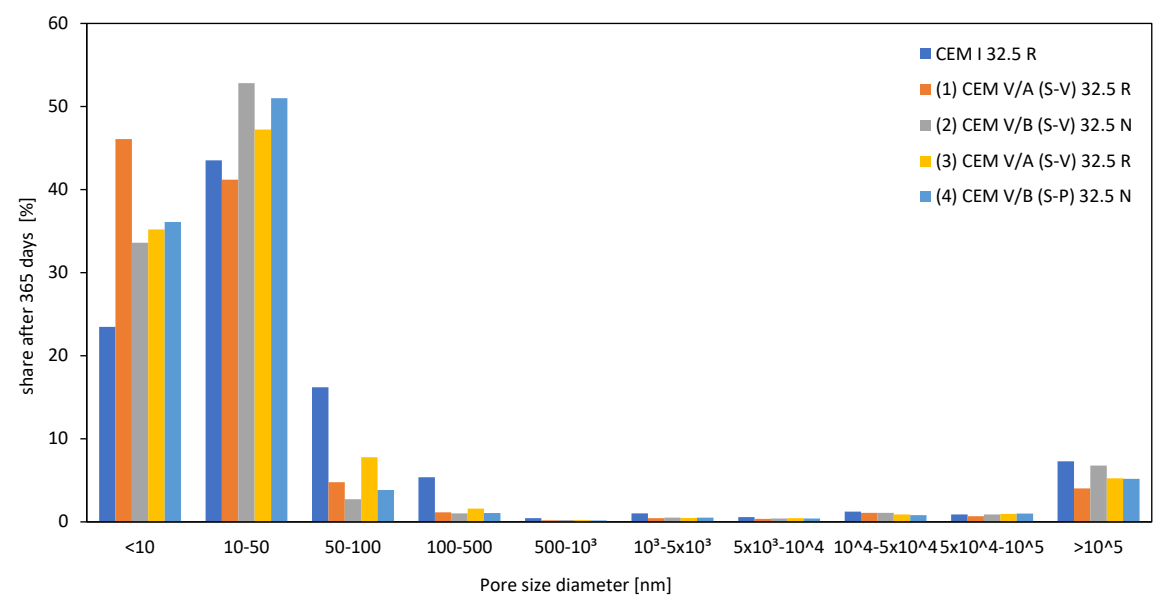

(b)

Figure 7. Comparison of pore-size distribution after 28 (a) and 365 days (b) curing time.

As illustrated in Figure 6, total porosity and percentage of macro-pores are clearly reduced during hydration of the Portland cement and -in the case of the CEM V cement types-the added cementitious constituents in the period from 28 to 365 days of curing. Therefore, CEM I $32.5 \mathrm{R}$ shows clearly the lowest total porosity (Figure 7a) with CEM V/B cement types approximately having 1.5 times as much total pore volume. However, CEM I cement also has the highest amount of macro pores (Figure $6 \mathrm{~b}$ ) at 28 and 365 days of curing time, nevertheless-due to its comparably low total porosity and highest short-term reactivity (because of the highest clinker content and lack of latent hydraulic and pozzolanic additives)—showing the highest compressive strength at 28 days age compared to the CEM V cement types.

Figure $7 \mathrm{a}, \mathrm{b}$ again compare the pore size distribution at 28 and 365 days of curing time, illustrating the change in pore structure. The pore structure of concretes made with CEM V-type cements shows typical symptoms of pore structure refinement in comparison with the reference CEM I concrete. During ongoing hydration, macro-pores with a diameter $>50-100 \mathrm{~nm}$ retreat in favor of pores with smaller diameters, in the case of the CEM V-cements, more significantly compared to the CEM I cement, leaving CEM I with the highest percentage of macro-pores and demonstrating the capability of CEM $\mathrm{V}$ cements' pore volume densification by pozzolanic reactions of the additives. This fact indicates the increase in the volume fraction of less permeable micropores, which is reflected in the increase in the total porosity but, on the contrary, in the decrease in permeability coefficient of concrete.

In addition, carbonation is an important topic concerning durability in terms of the passivation of the reinforcement steel. Slag-pozzolanic cements are known for their lowered resistance to carbonation compared to standard Portland cement by the consumption of the strong alkaline $\mathrm{Ca}(\mathrm{OH})_{2}$ during pozzolanic reactions as a counter-effect to that mentioned above $[5,56]$. The various cement types show $\mathrm{pH}$ values between 12.35 and 12.47 from their aqueous solution, indicating highly alkaline conditions. Additional $\mathrm{pH}$-testing of concrete samples using phenolphthalein indicator solution after 56 days (7 days curing in water, followed by air storage in the laboratory at $20{ }^{\circ} \mathrm{C}$ and approx. $60 \%$ relative humidity) was performed in addition. Therefore, phenolphthalein $\mathrm{pH}$-indicator solution was sprayed on cut-in-half concrete cubes. Areas with a $\mathrm{pH}$ value higher than 9.2 turn pink, whereas the concrete surface with a lower $\mathrm{pH}$ value stays colorless. Testing showed a carbonation depth $<0.5 \mathrm{~mm}$ for all CEM V cement types, indicating sufficient passivation, inter alia, because of its dense and highly impermeable concrete structure, keeping in mind that in this test stand, the curing conditions were not aggressive and the curing time was very short. The permeability subject of concrete made of CEM V-cements is further discussed in Sections 3 and 4. 


\section{Concrete Properties Using Slag-Pozzolanic Cement}

\subsection{Concrete Formula and Fresh Concrete Properties}

To evaluate and compare the performance of the different manufactured slag-pozzolanic cement types, concrete specimens were produced using a standard mixture (Table 5) with a water-binder- ratio of 0.5 , only varying the type of cement. In the case of cement types (3) CEM V/A (S-V) $32.5 \mathrm{R}$ and (4) CEM V/B (S-P) $32.5 \mathrm{~N}$, the addition of superplasticizer was necessary to reach a good workability of the fresh concrete with a flow spread of approximately $50 \mathrm{~mm}$ (consistency class F3 or F4 according to [57]).

Table 5. Concrete standard mixture for comparison of produced cement types.

\begin{tabular}{cc}
\hline Compound & Amount $\left[\mathbf{k g} / \mathrm{m}^{3}\right]$ \\
\hline Cement & 360 \\
Water & 176 \\
Aggregate $0 / 4 \mathrm{~mm}$ & 710 \\
Aggregate $4 / 8 \mathrm{~mm}$ & 420 \\
Aggregate $8 / 16 \mathrm{~mm}$ & 695 \\
\hline
\end{tabular}

For all mixtures, fresh concrete properties were determined in the laboratory and are summarized in Table 6.

Table 6. Fresh concrete properties by using different slag-pozzolanic cement types.

\begin{tabular}{cccc}
\hline Cement Type & $\begin{array}{c}\text { Fresh Concrete Density } \\
{\left[\mathbf{k g} / \mathbf{m}^{3}\right]}\end{array}$ & $\begin{array}{c}\text { Flow Spread Consistency [cm] and } \\
\text { (Consistency Class) According to [58] }\end{array}$ & Air Content [Vol.\%] \\
\hline CEM I 32.5 R & 2283 & $50(\mathrm{~F} 4)$ & 3.6 \\
(1) CEM V/A (S-V) 32.5 R & 2322 & $40(\mathrm{~F} 2)$ & 2.0 \\
(2) CEM V/B (S-V) 32.5 N & 2306 & $45(\mathrm{~F} 3)$ & 2.3 \\
(3) CEM V/A (S-V) 32.5 R & 2303 & $40(\mathrm{~F} 2)$ & 2.6 \\
(4) CEM V/B (S-P) 32.5 N & 2190 & $50(\mathrm{~F} 4)$ & 4.8 \\
\hline
\end{tabular}

In the case of (1) CEM V/A (S-V) $32.5 \mathrm{R}$ and (3) CEM V/A (S-V) $32.5 \mathrm{R}$, the consistency is plastic, not reaching a soft concrete consistency, indicating an additional demand for superplasticizers. Fresh concrete density is reasonable with the exception of (4) CEM V/B (S-P) $32.5 \mathrm{~N}$, showing a low density because of the high air content.

\subsection{Mechanical Properties of Concrete Using Slag-Pozzolanic Cement Types}

With regard to hardened concrete, compressive strength, bending tensile strength, and modulus of elasticity were evaluated for a basic characterization of the different cement types.

Compressive strength was tested on $150 \mathrm{~mm}$ concrete cubes after 2, 28, 90, and 365 days of water storage at $20 \pm 1{ }^{\circ} \mathrm{C}$ to present the varying strength development of the different cement or rather concrete types (Figure 8). As expected, the slag-pozzolanic cement types start at a low early strength level. CEM V/A cement types reach the strength level of the reference cement CEM I after 28 days and show a strength increase even between 90 and 365 days of concrete age. CEM V/B cements lag significantly behind, reaching a significantly lower strength level; strength development runs nearly flat after the age of 90 days. 


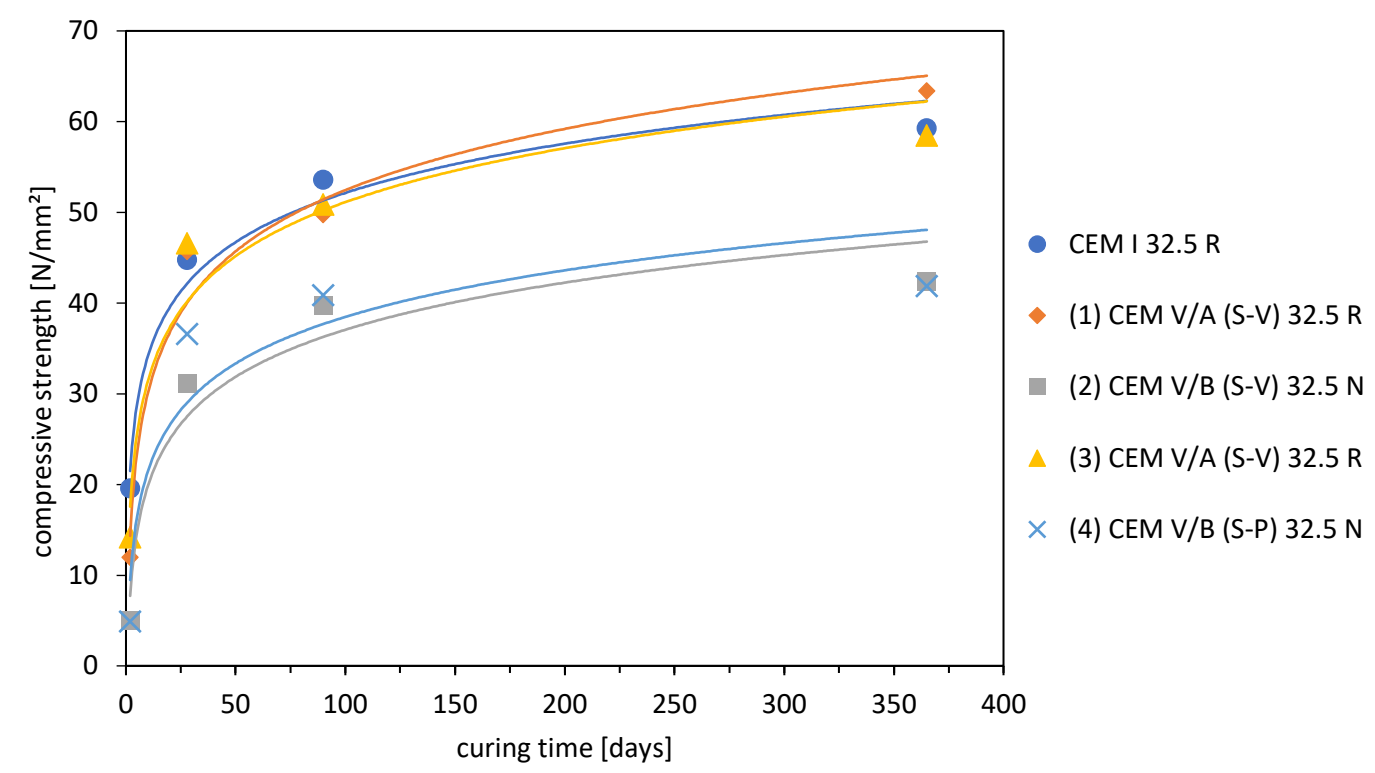

Figure 8. Concrete compressive strength using different cement types at 2, 28, and 90 days of water curing (each value as mean value of 3 individual tests).

The modulus of elasticity was determined as the secant under compression (the test specimen is loaded under axial compression, stresses and strains are recorded, and the slope of the secant to the stress-strain curve is determined) according to [58]. Test specimens (concrete prisms with dimensions of $150 \times 150 \times 600 \mathrm{~mm}$ ) were water-stored at $20 \pm 1{ }^{\circ} \mathrm{C}$ (the age-dependent pathway is displayed in Figure 9). The modulus of elasticity for the reference cement CEM I starts at approx. $30 \mathrm{GPa}$ at the highest level and shows a stronger increase with time than the concrete types made with slag-pozzolanic cement. All CEM V cement types reach a similar level of approx. $36 \mathrm{GPa}$ at a curing time of 365 days under water (see [49]).

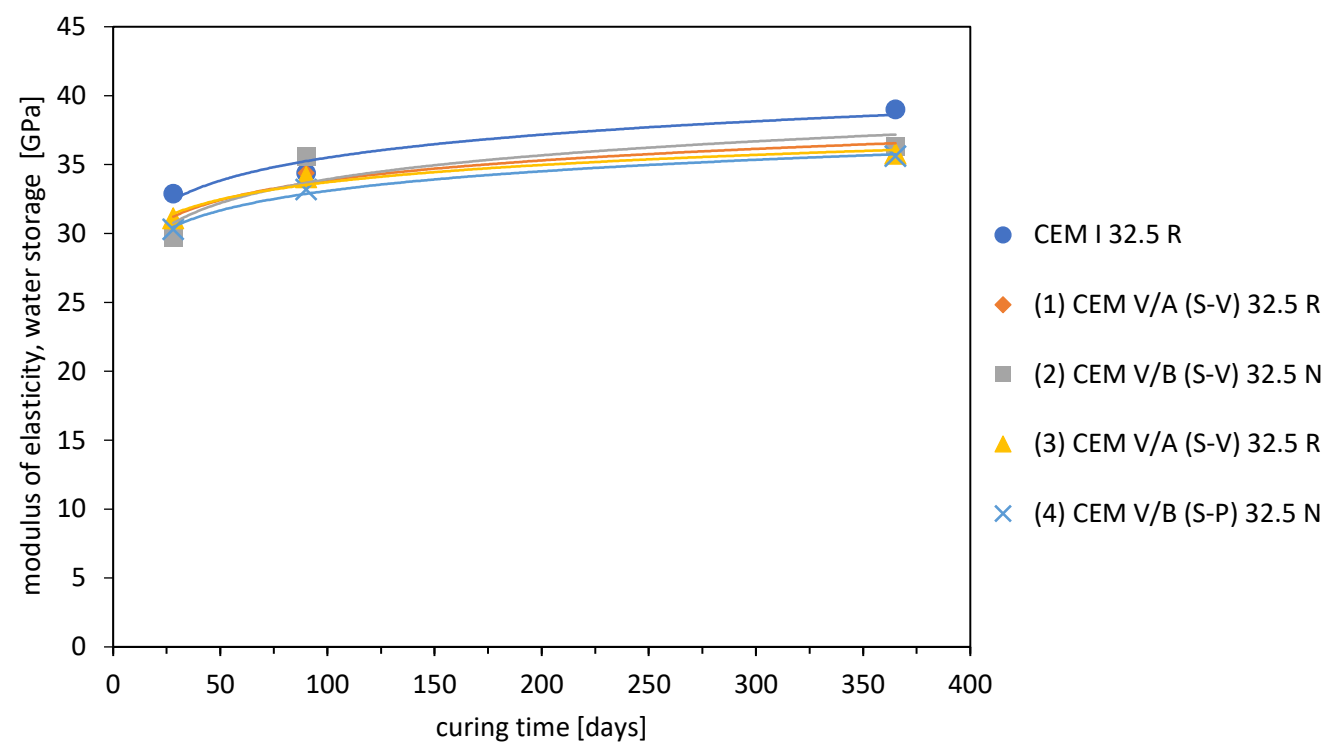

Figure 9. Modulus of elasticity (static) using different cement types at 2, 28, and 90 days of water curing (each value as mean value of 3 individual tests).

\subsection{Durability Aspects: Frost and Permeability of CEM V Concretes}

The negative effect of supplementary cementitious additives concerning frost resistance is well known, e.g., [59,60]. In this case, frost resistance could not be laboratory-confirmed during frost-testing, 
either. Testing was performed under intensified conditions without adding artificially entrained air additionally to the air content shown in Table 6 . Frost resistance was evaluated indirectly via reduction in the bending flexural strength after 50 frost-thawing cycles in demineralized water. One frost-thawing cycle takes $24 \mathrm{~h}$, whereby the temperature is lowered from the initial temperature of $20^{\circ} \mathrm{C}$ to $-20{ }^{\circ} \mathrm{C}$ within $12 \mathrm{~h}$, then kept at $-20^{\circ} \mathrm{C}$ for $4 \mathrm{~h}$ and subsequently raised again to the initial temperature within $8 \mathrm{~h}$. Temperature measurement is performed in the center of the concrete test specimen. Frost testing was performed after a period of 90 days of water curing at $150 \times 150 \times 600 \mathrm{~mm}$ samples. The results are illustrated in Figure 10: Bending flexural strength decreases strongly after frost impact, declining to a level between approx. 45 and 17\% in the case of (1) CEM V/A (S-V) 32.5 R to less than $10 \%$, indicating structural damage of the test specimen.

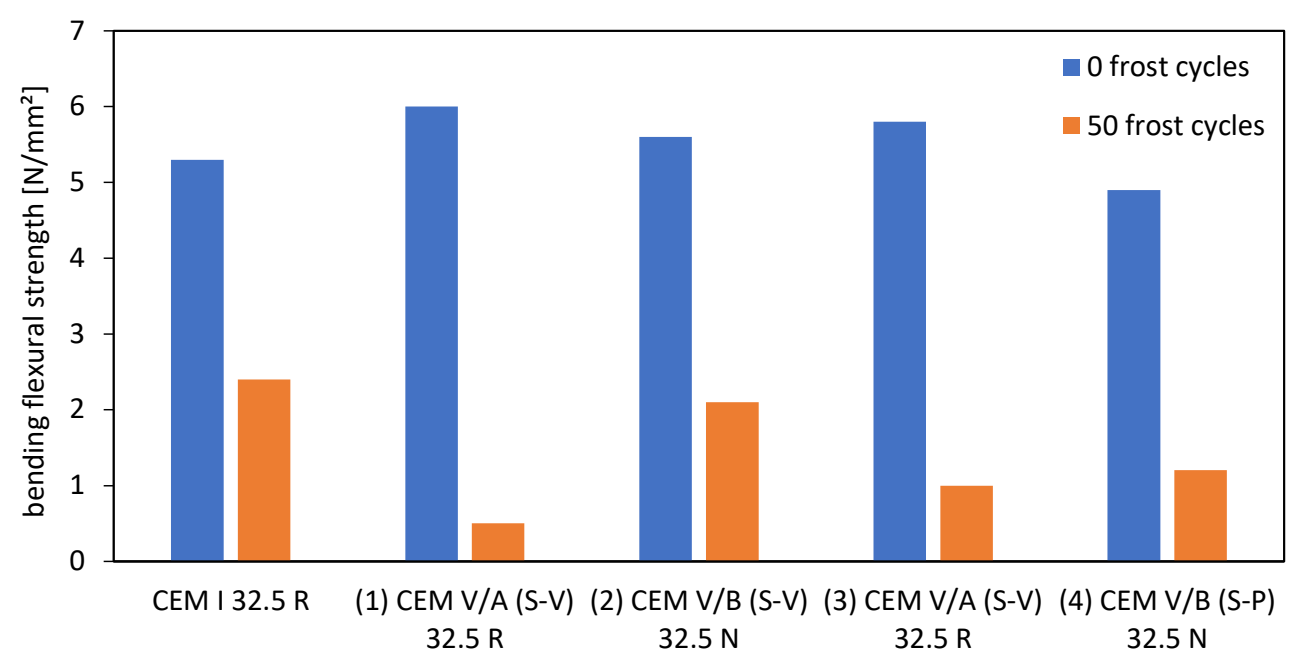

Figure 10. Bending flexural strength without and with frost impact evaluated after 90 days of water curing (each value as mean value of 3 individual tests).

Additional optimization of pore structure (porosity is reduced by the additives) and mixing design (high contents of additives increase the demand of water) will be necessary to improve frost resistance of the tested admixtures to prevent structural degradation of the concrete. An opportunity was used to build a concrete test track (washing station for trucks; Figure 11a,b) in a concrete factory in Austria in an alpine region (+815 m above the Adriatic Sea) using cement type (1) CEM V/A (S-V) $32.5 \mathrm{R}$. The concrete track itself is a horizontal structure experiencing a lot of water impact and mechanical exposure to truck tires. In winter, the input of chlorides by the truck tires is also most likely.

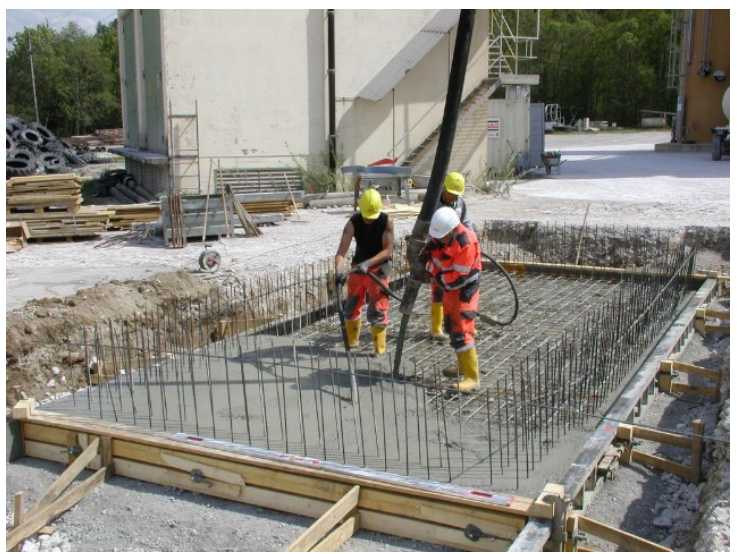

(a)

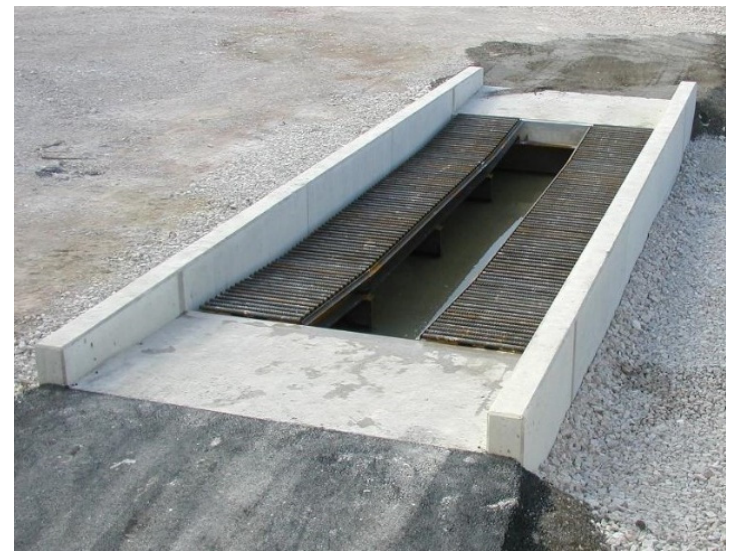

(b)

Figure 11. Test track construction using (1) CEM V/A (S-V) $32.5 \mathrm{R}$ using a cement content of $400 \mathrm{~kg} / \mathrm{m}^{3}$ and a water-binder ratio of 0.45 during (a) concreting work and (b) after finishing the construction. 
Considering the results from Figure 10, the mixture was adapted as the following: Cement content was increased to $400 \mathrm{~kg} / \mathrm{m}^{3}$, water-binder ratio was 0.45 , and plastifying admixture was added to reach a flow consistency of F3 to F4 according to [57], additionally using an air-entraining admixture to reach $5 \%$ of air content. The practical realization went well and the concrete structure showed no sign of damage after winter 2019/2020, imposing at least 25 frost-thawing-cycles, implying the frost resistance of the applied concrete mixture.

Permeability of the various concrete mixtures was tested via water pressure impact. Pressure testing was conducted for concrete cubes after 90 days of water curing at $20 \pm 1{ }^{\circ} \mathrm{C}$ and at atmospheric pressure according to [61]. Pressure testing was done at a water pressure of $500 \mathrm{kPa}$ for the duration of $72 \mathrm{~h}$. Afterward, the maximum depth of penetration was measured in millimeters. Water penetration depths for the different concrete mixtures with different CEM V-cements are illustrated in Figure 12.

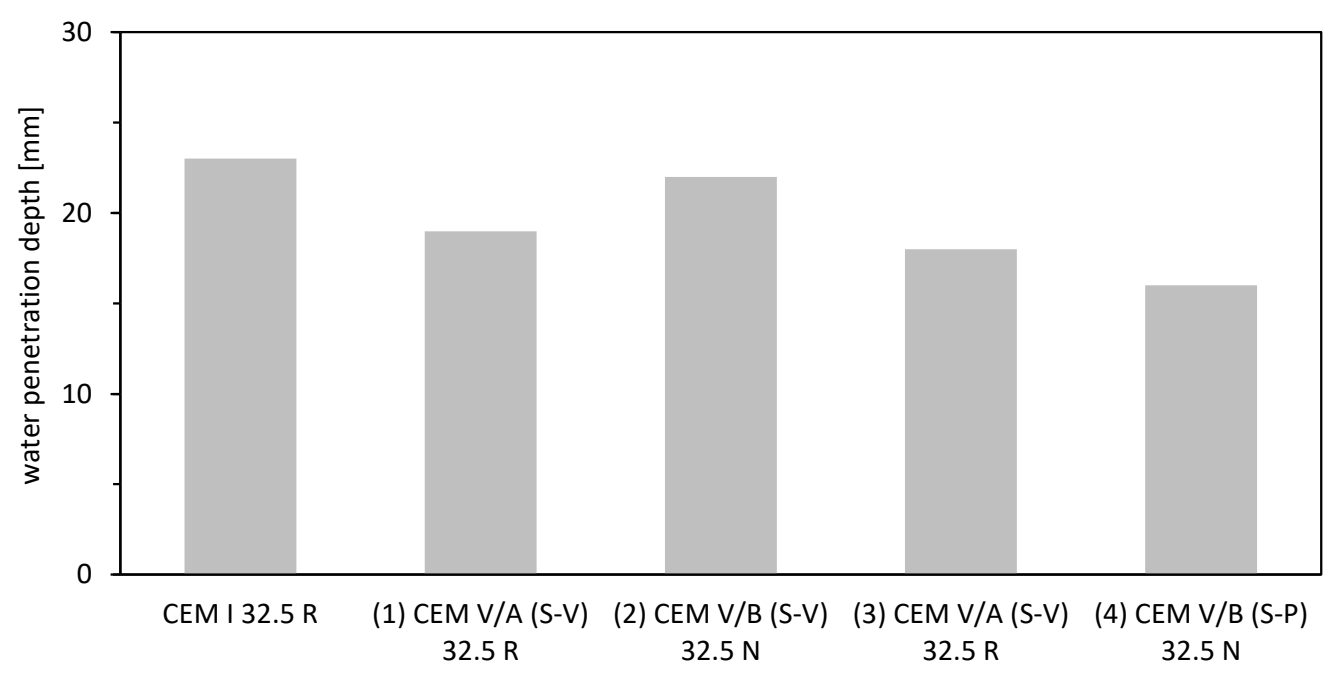

Figure 12. Water penetration depth (in $\mathrm{mm}$ ) after water pressure test (each value as mean value of 3 individual tests).

As evident from Figure 8, water penetration lies in the range of 16 to $23 \mathrm{~mm}$, whereby the water penetration was reduced by using the slag-pozzolanic cements. Especially, cement type (4) CEM V/B (S-P) $32.5 \mathrm{~N}$ shows a strongly reduced water penetration.

\section{Concrete Applying Recycled Aggregate and Slag-Pozzolanic Cement}

\subsection{General}

A new ecological approach was applied by merging the slag-pozzolanic cements with recycled rock aggregate from tunnel driving to maximize the environmental sustainability. For this reason, basic material characteristics were determined for a filling concrete mixture using three different rock types from excavation and a structural concrete mixture using aggregate from calcareous schist to evaluate the performance of the combination of CEM V cements and recycled rock material. Detailed information on the rock characteristics are given in $[28,62,63]$.

\subsection{Concrete Mixtures and Mechanical Characterization}

\subsubsection{Tentative Testing}

The concrete mix for filling concrete without requirements of concrete exposure classes according to [57], using CEM V cement types as binder and recycled aggregate from tunneling as aggregate, applies a low cement level of $220 \mathrm{~kg}_{\text {per }} \mathrm{m}^{3}$ of concrete, and the water-binder ratio was set at 0.55 to reach a flow spread of approx. $45 \mathrm{~mm}$ (consistency class F3 according to [57]). Maximum grain size was $31.5 \mathrm{~mm}$, whereby for the grain fraction of $0-4 \mathrm{~mm}$, standard quartz sand was used (to 
keep the water demand of the mixture at a manageable level concerning workability of the fresh concrete, because the high mica content of the finer fractions of recycled aggregates would increase water demand of the fresh concrete mix, see [28]), while fractions $4 / 8,8 / 16$, and 16/31.5 mm were produced from recycled rock material.

Three different types of aggregate were used from the tunnel driving of the Brenner Base Tunnel to determine the 28 day compressive strength (after 7 days of water storage and subsequent air storage at $20 \pm 1^{\circ} \mathrm{C}$ until 28 days of concrete age; Figure 13):

- Quartz phyllite (quartz phyllite of Innsbruck), characterized by its layered appearance and high-sheet silicate layers showing low to moderate rock strength.

- Calcareous schists (Bündner Schist), fine- to medium-grained, parallel-aligned structure consisting of mica-rich schist layers and layers mainly made of quartz and calcite showing mediocre rock strength.

- Gneiss (central Gneiss), medium- to coarse-grained orthogneiss with granoblastic texture and high rock strength.

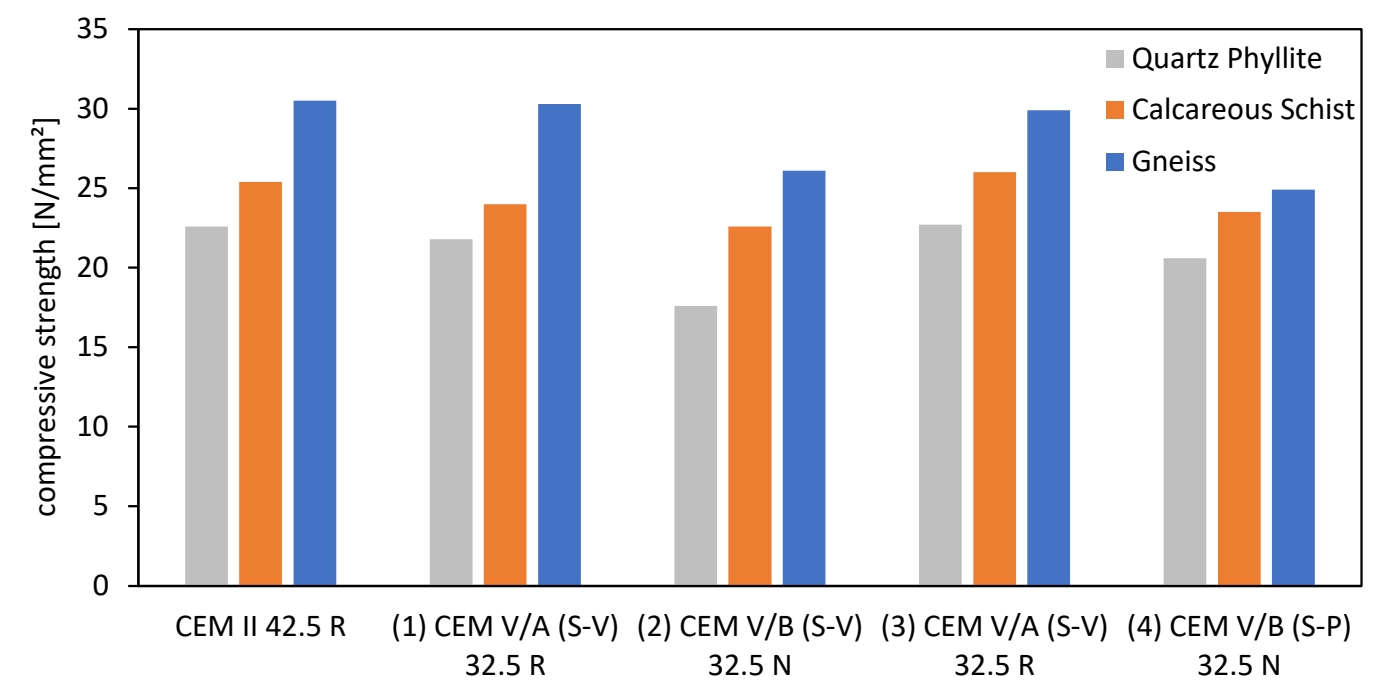

Figure 13. Compressive strength of various concrete mixtures varying cement and aggregate type (each value as mean value of 3 individual tests) after 28 days.

Figure 9 confirms the trend illustrated in Figure 6 (CEM V/B cement types show the lowest strength development after 28 days of curing time), additionally demonstrating the influence of the aggregate type: Quartz phyllite aggregate shows the lowest, calcareous schists aggregate shows mediocre, and gneiss aggregate shows the highest compressive strength due to rock characteristics, cf. [28].

\subsubsection{Inner Lining Concrete}

In order to use concrete with slag-pozzolanic binder and recycled aggregate, a concrete strength level of at least $50 \mathrm{~N} / \mathrm{mm}^{2}$ and a low permeability were defined as the crucial requirements. As calcareous schists are quantitatively dominant at the Brenner Base tunnel, cf. [28], concrete testing was performed using standard quartz aggregate for the grain fraction $0 / 4 \mathrm{~mm}$ and calcareous schists for $4 / 8,8 / 16$, and 16/31.5 mm. Cement content using (2) CEM V/B (S-V) $32.5 \mathrm{~N}$ was increased to a level of $330 \mathrm{~kg}$ per $\mathrm{m}^{3}$ of fresh concrete, and the water-binder-ratio was set to 0.52 . Superplasticizer was used to reach a flow spread of class F4 according to [57]. Test specimens were stored for 7 days under water with subsequent air storage until 28 days of concrete age. Fresh and hardened concrete properties are illustrated in Table 7, whereby fracture energy $G_{F}$ was determined by the cut-through-tensile splitting test. 
Table 7. Concrete properties of (1) CEM V/A (S-V) $32.5 \mathrm{R}$ cement type and calcareous schist aggregate.

\begin{tabular}{ccccccc}
\hline $\begin{array}{c}\text { Fresh Concrete Density } \\
{\left[\mathrm{kg} / \mathrm{m}^{3}\right]}\end{array}$ & $\begin{array}{c}\text { Flow Spread } \\
{[\mathrm{cm}]}\end{array}$ & $\begin{array}{c}\text { Air Content } \\
{[\mathrm{Vol} . \%]}\end{array}$ & $\begin{array}{c}\text { Hardened Concrete } \\
\text { Density }\left[\mathbf{k g} / \mathbf{m}^{3}\right]\end{array}$ & $\begin{array}{c}\text { Compressive } \\
\text { Strength } \mathbf{f}_{\mathrm{c}} \\
{\left[\mathbf{N} / \mathrm{mm}^{2}\right]}\end{array}$ & $\begin{array}{c}\text { Bending Flexural } \\
\text { Strength } \mathrm{f}_{\mathrm{ct}} \\
{\left[\mathrm{N} / \mathrm{mm}^{2}\right]}\end{array}$ & $\begin{array}{c}\text { Fracture Energy } \\
\mathbf{G}_{\mathrm{F}}[\mathrm{N} / \mathrm{m}]\end{array}$ \\
\hline 2411 & $55(\mathrm{~F} 4)$ & 2.5 & 2376 & 54.7 & 4.6 & 2.5 \\
\hline
\end{tabular}

The results from Table 7 show encouraging results concerning basic mechanical properties of the concrete composition, achieving good concrete density and workability of the fresh concrete, as well as a good strength level reaching concrete strength class C40/50 according to [57]. Figure 14 illustrates a concrete cube specimen after compressive strength testing.

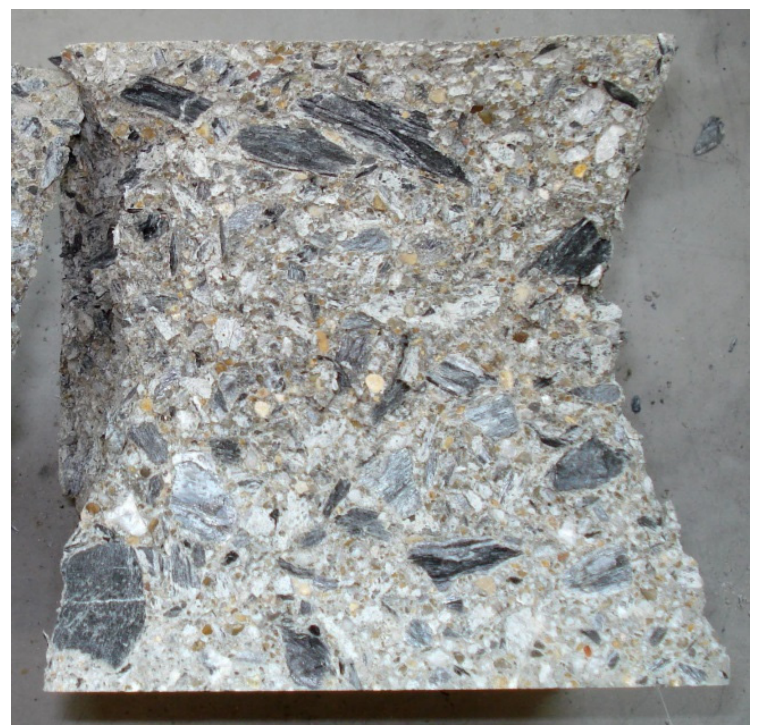

Figure 14. Concrete cube test specimen after compressive strength testing according to Table 7.

Water penetration testing was performed according to [64] with an initial water pressure of $175 \mathrm{kPa}$ for the first three days, subsequently increasing the water pressure to $700 \mathrm{kPa}$ up to the 14 th day. A water penetration depth of $19 \mathrm{~mm}$ could be determined, demonstrating a very low permeability comparable to the findings illustrated in Figure 8.

\section{Summary and Conclusions}

Cement production has a major contribution to global $\mathrm{CO}_{2}$ emission. Composite cements with a partial substitution of $\mathrm{CO}_{2}$-intensive clinker by additives, like slag, fly ash, or pozzolana, are a promising approach to make cement manufacture more environmentally friendly, reducing the $\mathrm{CO}_{2}$-impact by up to two-thirds. In this research, slag-pozzolanic cements (CEM V) were produced and evaluated regarding their composition and characteristics. To evaluate their performance as binder, various concrete admixtures were produced and tested, whereby the mechanical properties regarding strength and durability were of central importance. In order to further increase the life cycle assessment of concrete using CEM $\mathrm{V}$ cements with slag-pozzolanic additives, conventional aggregate was partly exchanged by recycled rock aggregate originating from tunnel driving of the Brenner Base Tunnel. The results obtained in this research could encourage both the national standardization and the cement/construction industry for future applications because of its environmental, economic, and durability characteristics. In the course of this work, the following conclusions could be drawn:

- Cementitious constituents were compared, whereby natural pozzolana zeolite $(\mathrm{P})$ showed the highest $\mathrm{SiO}_{2}$ content, and natural pozzolana zeolite $(\mathrm{P})$ also demonstrated the highest pozzolanic activity compared to fly ash (FA) and blast furnace slag (S). 
- The $\mathrm{CaO}$ content (crucial with regard to $\mathrm{ECO}_{2}$-generation) of the manufactured CEM V cement types was considerably smaller compared to CEM I Portland cement.

- Individual CEM V types showed low slump values, indicating the need of superplasticizer to obtain good workability.

- Natural pozzolana zeolite $(\mathrm{P})$ indicated a low fresh mortar density due to the porous tectosilicate structure, also containing a higher amount of air

- Compressive strength development was naturally behind CEM I cement types, whereby CEM $\mathrm{V} / \mathrm{B}$ cement types with a higher proportion of additives showed lower strength (approximately 20 to $30 \%$ ) after 90 days of curing time, at which there were no major differences considering bending tensile strength.

- Slag-pozzolanic cement types indicated high durability because of their lower porosity and permeability compared to Portland cement.

- Considering concrete production, different CEM V cement types showed a higher demand for superplasticizer to reach a good workability of fresh concrete; CEM V with natural pozzolana zeolite $(\mathrm{P})$ again showed a high air content and low fresh concrete density.

- Concrete compressive strength and bending tensile strength development corresponded to the cement strength development.

- Water penetration of CEM V concrete admixtures was considerably smaller compared to Portland cement.

- Frost resistance of CEM V concretes via reduction in the bending tensile strength after freezing could not be verified in the laboratory, but could be verified at large scale using $400 \mathrm{~kg}$ of CEM V cement per $\mathrm{m}^{3}$ fresh concrete and increasing the air content to $5 \%$.

- Additional aggregate recycling was tested using different processed rock types from tunneling: Mechanical characteristics, especially water permeability, are promising for the usability of such concrete types.

In conclusion, it can be said that alternative cement types with reduced clinker content have their legitimacy for many application areas regarding their special characteristics discussed in this paper. Recycling of tunnel excavation material has already been proven at different construction projects and works well considering the essential framework conditions. In both cases, there is often a lack of experience impeding the practical implementation of these two alternatives.

Author Contributions: Conceptualization, K.V. and O.Z.; methodology, K.V., I.J., R.A. and K.B.; validation, K.V. and O.Z.; formal analysis, K.V. and I.J.; investigation, K.V. and I.J.; writing-original draft preparation, K.V. and O.Z.; writing-review \& editing, I.J. and K.B.; visualization, K.V. and O.Z.; supervision, K.B.; project administration, K.V., I.J. and K.B.; funding acquisition, I.J. and K.B. All authors have read and agreed to the published version of the manuscript.

Funding: This research was funded by the EUROPEAN UNION European Regional Development Fund. Open-access funding provided by BOKU Vienna Open Access Publishing Fund. The authors would like to acknowledge the financial and technical support.

Conflicts of Interest: The authors declare no conflict of interest.

\section{References}

1. Shi, C.; Jiménez, A.F.; Palomo, Á. New cements for the 21st century: The pursuit of an alternative to Portland cement. Cem. Concr. Res. 2011, 41, 750-763. [CrossRef]

2. Zhang, C.-Y.; Han, R.; Yu, B.; Wei, Y.-M. Accounting process-related CO2 emissions from global cement production under Shared Socioeconomic Pathways. J. Clean. Prod. 2018, 184, 451-465. [CrossRef]

3. Chen, C.-H.; Lee, C.-M.; Tung, W.-C.; Wang, J.-H.; Hung, C.-H.; Hu, T.-H.; Wang, J.-C.; Lu, S.-N.; Changchien, C.-S. Evolution of full-length HBV sequences in chronic hepatitis B patients with sequential lamivudine and adefovir dipivoxil resistance. J. Hepatol. 2010, 52, 478-485. [CrossRef] [PubMed]

4. Uwasu, M.; Hara, K.; Yabar, H. World cement production and environmental implications. Environ. Dev. 2014, 10, 36-47. [CrossRef] 
5. Limbachiya, M.; Bostanci, S.C.; Kew, H. Suitability of BS EN 197-1 CEM II and CEM V cement for production of low carbon concrete. Constr. Build. Mater. 2014, 71, 397-405. [CrossRef]

6. Ofosu-Adarkwa, J.; Xie, N.; Javed, S.A. Forecasting $\mathrm{CO}_{2}$ emissions of China's cement industry using a hybrid Verhulst-GM(1,N) model and emissions' technical conversion. Renew. Sustain. Energy Rev. 2020, 130, 109945. [CrossRef]

7. Barker, D.; Turner, S.; Napier-Moore, P.; Clark, M.; Davison, J. $\mathrm{CO}_{2}$ Capture in the Cement Industry. Energy Procedia 2009, 1, 87-94. [CrossRef]

8. Bosoaga, A.; Masek, O.; Oakey, J.E. $\mathrm{CO}_{2}$ Capture Technologies for Cement Industry. Energy Procedia 2009, 1, 133-140. [CrossRef]

9. Hills, T.; Leeson, D.; Florin, N.; Fennell, P.S. Carbon Capture in the Cement Industry: Technologies, Progress, and Retrofitting. Environ. Sci. Technol. 2015, 50, 368-377. [CrossRef]

10. Deja, J.; Uliasz-Bochenczyk, A.; Mokrzycki, E. $\mathrm{CO}_{2}$ emissions from Polish cement industry. Int. J. Greenh. Gas Control. 2010, 4, 583-588. [CrossRef]

11. Anand, S.; Vrat, P.; Dahiya, R. Application of a system dynamics approach for assessment and mitigation of $\mathrm{CO}_{2}$ emissions from the cement industry. J. Environ. Manag. 2006, 79, 383-398. [CrossRef] [PubMed]

12. The Concrete Centre. Embodied Carbon Dioxide $\left(\mathrm{CO}_{2}\right.$ e) of Concretes Used in Buildings; MPA The Concrete Centre: London, UK, 2013.

13. Flower, D.J.M.; Sanjayan, J.G. Green house gas emissions due to concrete manufacture. Int. J. Life Cycle Assess. 2007, 12, 282-288. [CrossRef]

14. Purnell, P.; Black, L. Embodied carbon dioxide in concrete: Variation with common mix design parameters. Cem. Concr. Res. 2012, 42, 874-877. [CrossRef]

15. Biernacki, J.J.; Bullard, J.W.; Sant, G.; Brown, K.; Glasser, F.P.; Jones, S.; Ley, T.; Livingston, R.; Nicoleau, L.; Olek, J.; et al. Cements in the 21stcentury: Challenges, perspectives, and opportunities. J. Am. Ceram. Soc. 2017, 100, 2746-2773. [CrossRef]

16. Proaño, L.; Sarmiento, A.; Figueredo, M.; Cobo, M. Techno-economic evaluation of indirect carbonation for $\mathrm{CO}_{2}$ emissions capture in cement industry: A system dynamics approach. J. Clean. Prod. 2020, 263, 121457. [CrossRef]

17. Schneider, M. The cement industry on the way to a low-carbon future. Cem. Concr. Res. 2019, 124, 105792. [CrossRef]

18. Mikulčić, H.; Vujanović, M.; Markovska, N.; Filkoski, R.V.; Ban, M.; Duić, N. $\mathrm{CO}_{2}$ Emission Reduction in the Cement Industry. Chem. Eng. Trans. 2003, 35, 703-708. [CrossRef]

19. De Carvalho, J.M.F.; De Melo, T.V.; Fontes, W.C.; Batista, J.O.D.S.; Brigolini, G.J.; Peixoto, R.A.F. More eco-efficient concrete: An approach on optimization in the production and use of waste-based supplementary cementing materials. Constr. Build. Mater. 2019, 206, 397-409. [CrossRef]

20. Deolalkar, S. Composite Cements. In Designing Green Cement Plants; Elsevier Science: Amsterdam, The Netherlands, 2016; pp. 41-44.

21. Salazar, R.A.R.; Valencia-Saavedra, W.; De Gutiérrez, R.M. Construction and Demolition Waste (CDW) Recycling-As Both Binder and Aggregates-In Alkali-Activated Materials: A Novel Re-Use Concept. Sustainability 2020, 12, 5775. [CrossRef]

22. ÖNORM EN 197-1: Cement-Part 1: Composition, Specification and Conformity Criteria for Common Cements; Edition 2018-12; Austrian Standards International: Vienna, Austria, 2018.

23. Tam, V.W.Y.; Soomro, M.; Evangelista, A.C.J. A review of recycled aggregate in concrete applications (2000-2017). Constr. Build. Mater. 2018, 172, 272-292. [CrossRef]

24. Malešev, M.; Radonjanin, V.; Marinković, S. Recycled Concrete as Aggregate for Structural Concrete Production. Sustainability 2010, 2, 1204-1225. [CrossRef]

25. Working Group 14 \& 15, ITA Report No. 21: Handling, Treatment and Disposal of Tunnel Spoil Materials. Working Groups 14 and 15-Underground Construction and the Environment and Mechanized Tunneling; International Tunneling and Underground Space Association ITA: Châtelaine, Switzerland, 2019; ISBN 978-2-9701242-0-7.

26. Burger, D.; Kohlböck, B.; Schoitsch, C. Geotechnics and mass balance of the earthworks for the second tube of the Tauern Tunnel. Geomech. Tunn. 2010, 3, 391-401. [CrossRef]

27. Bellopede, R.; Brusco, F.; Oreste, P.; Pepino, M. Main Aspects of Tunnel Muck Recycling. Am. J. Environ. Sci. 2011, 7, 338-347. [CrossRef] 
28. Bellopede, R.; Marini, P. Aggregates from tunnel muck treatments. Properties and uses. Physicochem. Probl. Miner. Process. 2011, 47, 259-266.

29. Voit, K.; Kuschel, E. Rock Material Recycling in Tunnel Engineering. Appl. Sci. 2020, 10, 2722. [CrossRef]

30. Thalmann, C. Characterisation and Possibilities of the Utilisation of Excavated Rock Material by Tunneling Boring Machines as Concrete and Shotcrete Aggregates. Ph.D. Thesis, Swiss Federal Institute of Technology Zurich (ETH), Zürich, Switzerland, 1996.

31. Gertsch, L.; Fjeld, A.; Nilsen, B. Use of TBM muck as construction material. Tunn. Undergr. Space Technol. 2000, 15, 379-402. [CrossRef]

32. Oggeri, C.; Fenoglio, T.M.; Vinai, R. Tunnel spoil classification and applicability of lime addition in weak formations for muck reuse. Tunn. Undergr. Space Technol. 2014, 44, 97-107. [CrossRef]

33. Ritter, S.; Einstein, H.H.; Galler, R. Planning the handling of tunnel excavation material-A process of decision making under uncertainty. Tunn. Undergr. Space Technol. 2013, 33, 193-201. [CrossRef]

34. Erben, H.; Galler, R. Tunnel spoil-New technologies on the way from waste to raw material/Tunnelausbruch-Neue Technologien für den Weg vom Abfall zum Rohstoff. Géoméch. Tunn. 2014, 7, 402-410. [CrossRef]

35. Reichel, P. Tunnel spoil: Tipping or the end of the definition as waste/Tunnelausbruch: Deponierung oder Abfallende. Géoméch. Tunn. 2014, 7, 419-427. [CrossRef]

36. Posch, H.; Murr, R.; Huber, H.; Kager, M.; Kolb, E. Tunnel excavation-The conflict between waste and recycling through the example of the Koralm Tunnel, contract KAT2/Tunnelausbruch—Das Spannungsfeld zwischen Abfall und Verwertung am Beispiel Koralmtunnel, Baulos KAT2. Géoméch. Tunn. 2014, 7, 437-450. [CrossRef]

37. Bergmeister, K. Brenner Base Tunnel-Innovative Solutions in Tunneling; Österreichische Ingenieur- und Architekten-Zeitschrift: Vienna, Germany, 2018.

38. BLS AlpTransit Lötschberg: Final report Logistics in Excavation and Material Management (Schlussbericht Logistik Ausbruch- und Materialbewirtschaftung). IG-LBT Ingenieurgemeinschaft Lötschberg-Basistunnel; BLS AlpTransit AG: Thun, Switzerland, 2008. (In German)

39. Lieb, R.H. Materials management at the Gotthard Base Tunnel-Experience from 15 years of construction. Géoméch. Tunn. 2009, 2, 619-626. [CrossRef]

40. Resch, D.; Lassnig, K.; Galler, R.; Ebner, F. Tunnel excavation material-High value raw material. Géoméch. Tunn. 2009, 2, 612-618. [CrossRef]

41. Erdem, T.K.; Kırca, Ö. Use of binary and ternary blends in high strength concrete. Constr. Build. Mater. 2008, 22, 1477-1483. [CrossRef]

42. Khatri, R.; Sirivivatnanon, V.; Gross, W. Effect of different supplementary cementitious materials on mechanical properties of high performance concrete. Cem. Concr. Res. 1995, 25, 209-220. [CrossRef]

43. Bjegović, D.; Stirmer, N.; Serdar, M. Durability properties of concrete with blended cements. Mater. Corros. 2012, 63, 1087-1096. [CrossRef]

44. Asadollahfardi, G.; Yahyaei, B.; Salehi, A.M.; Ovesi, A. Effect of admixtures and supplementary cementitious material on mechanical properties and durability of concrete. Civ. Eng. Des. 2020, 2, 3-11. [CrossRef]

45. ÖNORM B 4710-1: Concrete-Part 1: Specification, Performance, Production, Use and Conformity-Part 1: Rules for the Implementation of ÖNORM EN 206-1 for Normal and Heavy Concrete; Edition 2018-01; Austrian Standards International: Vienna, Austria, 2018.

46. DIN 1045-2: Concrete, Reinforced and Prestressed Concrete Structures-Part 2: Concrete-Specification, Proper-Ties, Production and Conformity-Application Rules for DIN EN 206-1; Edition 2008-08; Construction committee of the DIN: Berlin, Germany, 2008.

47. Janotka, I.; Bergmeister, K.; Voit, K.; Zeller, H.; Bagel, L.; Sevcik, P. Verification of Austrian and Slovak CEM $\mathrm{V}(\mathrm{A}, \mathrm{B})$ cement kinds for the use in structural concrete. In Proceedings of the International congress on durability of concrete, Trondheim, Norway, 18-21 June 2012.

48. ÖNORM EN 196-5: Methods of Testing Cement_Part 5: Pozzolanicity Test for Pozzolanic Cement; Edition 2011-06; Austrian Standards International: Vienna, Austria, 2011.

49. ENVIZEO: Nutzung der Ökozementsorten CEM V (A, B) Gemäß EN 197-1 in Konstruktionsbeton; Project report; Janotka, I. (Ed.) Self-Published: Bratislava, Slovakia, 2013.

50. ÖNORM EN 196-1: Methods of Testing Cement-Part 1: Determination of Strength; Edition 2016-10; Austrian Standards International: Vienna, Austria, 2016. 
51. ÖNORM EN 196-3: Methods of Testing Cement-Part 3: Determination of Setting Times and Soundness; Edition 2017-01; Austrian Standards International: Vienna, Austria, 2017.

52. Dziuk, D.; Giergiczny, Z.; Sokołowski, M.; Puz, T. Concrete resistant to aggressive media using a composite cement CEM V/A (S-V) 32.5 R-LH. In Underground Infrastructure of Urban Areas 2; CRC Press: Boca Raton, FL, USA, 2011; Volume 2, pp. 12-21. [CrossRef]

53. Li, Y.-X.; Chen, Y.-M.; Wei, J.-X.; He, X.-Y.; Zhang, H.-T.; Zhang, W.-S. A study on the relationship between porosity of the cement paste with mineral additives and compressive strength of mortar based on this paste. Cem. Concr. Res. 2006, 36, 1740-1743. [CrossRef]

54. ASTM UOP578-02, Automated Pore Volume and Pore Size Distribution of Porous Substances by Mercury Porosimetry; ASTM International: West Conshohocken, PA, USA, 2003.

55. ISO 15901-1: Evaluation of Pore Size Distribution and Porosity of Solid Materials by Mercury Porosimetry and Gas Adsorption-Part 1: Mercury Porosimetry; International Organization for Standardization ISO: Geneva, Switzerland, 2013.

56. Smrčková, E.; Bačuvčík, M.; Janotka, I. Basic Characteristics of Green Cements of CEM V/A and V/B Kind. Adv. Mater. Res. 2014, 897, 196-199. [CrossRef]

57. ÖNORM EN 206-1: Concrete-Specification, Performance, Production and Conformity; Edition 2017-05; Austrian Standards International: Vienna, Austria, 2017.

58. EN 12390-13: Testing Hardened Concrete. Part 13: Determination of Secant Modulus of Elasticity in Compression; Edition 2013; Austrian Standards International: Vienna, Austria, 2013.

59. Łaźniewska-Piekarczyk, B.; Piekarczyk, A. The problem of the equivalent time to start the internal frost resistance test on self-compacting concrete with supplementary cementitious materials. J. Build. Eng. 2020, 32, 101503. [CrossRef]

60. Reiterman, P.; Holčapek, O.; Zobal, O.; Keppert, M. Freeze-Thaw Resistance of Cement Screed with Various Supplementary Cementitious Materials. Rev. Adv. Mater. Sci. 2019, 58, 66-74. [CrossRef]

61. EN 12390-8: Testing Hardened Concrete. Part 8: Depth of Penetration of Water under Pressure; Edition 2009; Austrian Standards International: Vienna, Austria, 2009.

62. Voit, K. Application and Optimization of Tunnel Excavation Material of the Brenner Base Tunnel. Ph.D. Thesis, University of Natural Resources and Life Sciences, Vienna, Austria, 2013.

63. Voit, K.; Zimmermann, T. Characteristics of selected concrete with tunnel excavation material. Constr. Build. Mater. 2015, 101, 217-226. [CrossRef]

64. ONR 23303: Test Methods for Concrete-National Application of Testing Standards for Concrete and Its Source Materials; Edition 2010; Austrian Standards International: Vienna, Austria, 2010.

Publisher's Note: MDPI stays neutral with regard to jurisdictional claims in published maps and institutional affiliations.

(C) 2020 by the authors. Licensee MDPI, Basel, Switzerland. This article is an open access article distributed under the terms and conditions of the Creative Commons Attribution (CC BY) license (http://creativecommons.org/licenses/by/4.0/). 